\title{
Monitoring of Sea-Ice-Atmosphere Interface in the Proximity of Arctic Tidewater Glaciers: The Contribution of Marine Robotics
}

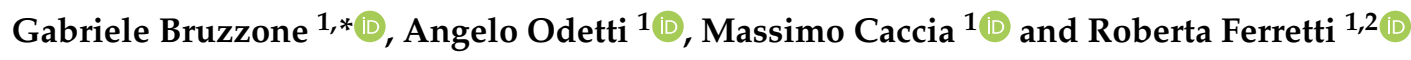 \\ 1 Consiglio Nazionale delle Ricerche, Istituto di iNgegneria del Mare CNR-INM, Uos Genoa, Via de Marini, \\ 6-16149 Genova, Italy; angelo.odetti@inm.cnr.it (A.O.); massimo.caccia@cnr.it (M.C.); \\ roberta.ferretti@inm.cnr.it (R.F.) \\ 2 UniFe Dipartimento di Fisica e Scienze della Terra, Università degli Studi di Ferrara, Via Saragat, \\ 1-44122 Ferrara, Italy \\ * Correspondence: gabriele.bruzzone@cnr.it
}

Received: 6 April 2020; Accepted: 25 May 2020; Published: 27 May 2020

\begin{abstract}
The Svalbard archipelago, with its partially closed waters influenced by both oceanic conditions and large tidal glaciers, represents a prime target for understanding the effects of ongoing climate change on glaciers, oceans, and ecosystems. An understanding of the role played by tidewater glaciers in marine primary production is still affected by a lack of data from close proximity to glacier fronts, to which, for safety reasons, manned surface vessels cannot get too close. In this context, autonomous marine vehicles can play a key role in collecting high quality data in dangerous interface areas. In particular, the contribution given by light, portable, and modular marine robots is discussed in this paper. The state-of-the-art of technology and of operating procedures is established on the basis of the experience gained in campaigns carried out by Italian National Research Council (CNR) robotic researchers in Ny-Ålesund, Svalbard Islands, in 2015, 2017, and 2018 respectively. The aim was to demonstrate the capability of an Unmanned Semi-Submersible Vehicle (USSV): (i) To collect water samples in contact with the front of a tidewater glacier; (ii) to work in cooperation with Unmanned Aerial Vehicles (UAV) for sea surface and air column characterisation in the proximity of the fronts of the glaciers; and (iii) to perform, when equipped with suitable tools and instruments, repetitive sampling of water surface as well as profiling the parameters of the water and air column close to the fronts of the tidewater glaciers. The article also reports the issues encountered in navigating in the middle of bergy bits and growlers as well as the problems faced in using some sensors at high latitudes.
\end{abstract}

Keywords: arctic; marine robotics; UMV; USSV; USV; UAV; monitoring; tidewater glaciers; svalbard

\section{Introduction}

Over the last decade, Arctic-average temperatures have increased to become twice as high as the global average and the Northern environment has been in a rapid and unstable transition as a result of global climate change [1]. This has brought a rapid local environmental change that is increasingly evident in the observations of many geophysical and biological properties. The interactions between atmosphere, ocean, cryosphere, and biosphere are responsible for the phenomenon known as Arctic amplification. The stronger augment of global warming in this region can be attributed to various feedback mechanisms present in the Arctic environment. Some processes are locally confined to the diminishing sea ice cover of the Arctic ocean [2]. Other amplifying processes are related to the increasing open water surface of the Arctic ocean and to land-ice melt. The latter phenomenon was initially underestimated by the 4th Assessment (2007) of the Intergovernmental Panel on Climate 
Change (IPCC) [3]), and was taken into consideration in the IPCC 5th Assessment (2013) [4]. Nowadays most scientists foresee that the global land-ice melt is continuously increasing with unpredictable feedback effects on the ecosystem.The presence of Arctic amplification, as well as its geographical position on the border between the Atlantic and Arctic waters [5], makes the Svalbard Islands and, in particular, its glaciers a key site for understanding the effects of ongoing climate change on glaciers, oceans, and ecosystems [6]. The observations from the West coast of the Svalbard archipelago show an annual temperature increase of $1.4 \mathrm{~K}$ with the consequent rapid retreating of tidewater glaciers and it is expected that they will terminate on land at some time in the future [7]. This seems to be inevitable. Since the large-scale circulation within the inner fjord is influenced by the melting of tidewater glacier fronts, a transition to a fjord with only land-terminating glaciers will affect the fjord circulation with sudden implications for the entire ecosystem of Kongsfjorden. As much as physical processes occurring in the Svalbard fjords have an influence on the local environment, a large-scale fall-out on the global environment can be expected.

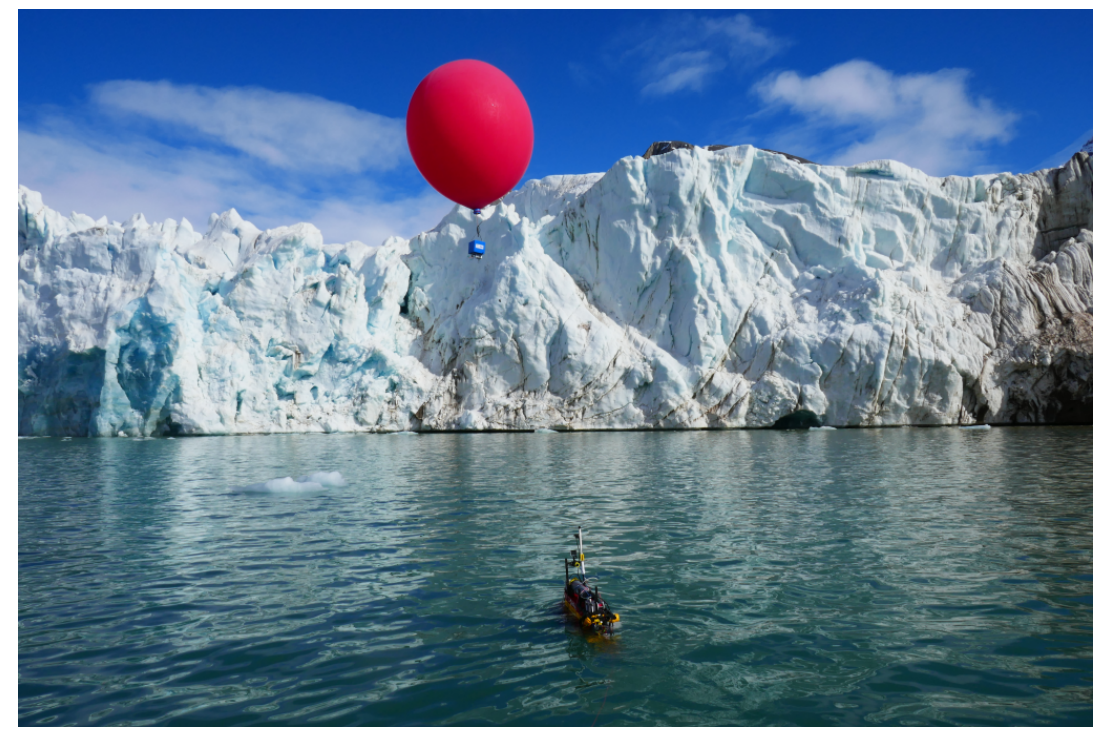

Figure 1. PROTEUS (Portable RObotic TEchnology for Unmanned Surveys) vehicle with atmospheric sensors in the 2018 campaign carried out by CNR-INM in Svalbard.

The IPCC projections were underestimated because sea ice retreat itself was underestimated as projections were based on climate models that failed to include the effects of some of the small-scale but critical processes involved. Understanding the processes should involve all the local effects with a completion of acquired data. As an example, Arctic tidewater glaciers are retreating and this will locally affect the fjord circulation and ecosystems when glacier fronts become land terminating. In addition, the extended mass loss make glaciers the most important cryospheric contributors to global eustatic sea-level rise.

Recent reports in Svalbard observations [8] focus on knowledge gaps and recommendations on the future. In particular it is becoming evident that local observations indicate that climate change and shifting disturbance regimes are causing a series of changes that have a feedback action on the Arctic environment.

The overview knowledge of the scenarios together with sea-ice, permafrost, and glacial topography of retreating glaciers is important in modelling future scenarios of fjord circulation and glacier dynamics. The remote sensing models with their high-resolution digital data allow an overview of the situation [6,9] but these methods are limited by the need of a ground-truth and do not give the possibility of analysing local compositions. For this reason, local land observations have to be performed. However, in particular for ocean observation, the widespread and quality of observations cannot be carried out with traditional methods. Particularly interesting is the case of monitoring 
the calving front of tidewater glaciers. In these hazardous areas the most direct observations were traditionally performed operating from surface vessels that, for safety reasons, had to maintain a safe recommended distance (typically farther than $200 \mathrm{~m}$ ) [10] from the glacier. For this reason, a complete data acquisition in the whole area could not be performed.

In recent years, a number of research groups are trying to fill the gap of data in the Arctic environment by means of robotic applications. With the primary goal of reducing risk to field workers in 2010 an Unmanned Surface Vehicle (USV) based on a dinghy hull, [11] was designed as a remote-controlled glacier-surveying robot, capable of taking accurate above- and below-water measurements of calving glacier fronts, using swath bathymetry and laser scanning hardware. In 2012, the boat Minty2 [12], expressly designed for polar environment, was taken to Greenland to attempt a survey of the Lille Glacier near Uummannaq where problems with the radio modem, GPS, compass, and weather conditions prevented the mission to be accomplished showing the difficulties that can be encountered in this environment. The large size of the two USVs also proved to the research group the need for using reduced logistics.

In 2014, the use of a gasoline-based vehicle, the JETYAK [13], highlighted the usability of Autonomous Surface Vehicles (ASVs) near calving glaciers. The survey had a multibeam sonar of the calving front, which allowed the shape profiles of the Sarqardleq Glacier in Greenland to be obtained with a surface vehicle, operating in an area forbidden to Autonomous Underwater Vehicles (AUVs) due to the shallow depths.

In 2016 overcoming navigation difficulties in the acoustically noisy, iceberg-filled fjord, the same research group [14] used a REMUS-100 AUV that covered a large portion of the near-ice waters along the terminus of the Sarqardleq Fjord. This provided several new observational insights to the characteristics and distribution of near-ice area.

Recently new solutions are being developed to increase the number of data collected. As an example, an Unmanned Aerial Vehicle- (UAV) based solution with the IceDrone [15] demonstrated the potential for unmanned aerial drone systems to aid in ice sampling operations. Another example is ARCAB [16], an open-source ASV expressly targeted for harsh polar environments that responds with lightness, cheapness, and reliability. ARCAB operated autonomously in winter-time conditions in Greenland and measured bathymetry and ocean currents in shallow and rocky areas that would make the use of manned vessels too risky.

As discussed in [17], robotics can provide effective solutions to collect high quality data in hazardous environment, mitigating risks. Indeed, the use of a Teledyne Gavia Offshore Surveyor 'Freya' operated from the Norwegian Polar Institute vessel MS Teisten allowed in 2016 and 2017, a high resolution mapping of bathymetry and Conductivity-Temperature-Depth (CTD) profiles in front of Fjortende Julibreen, Conwaybreen, Kongsbreen, and Kronebreen glaciers in Svalbard.

In the same years, from 2015 to 2018, field experimental activity carried out by Italian National Research Council (CNR) researchers in the Arctic regions supported the evaluation and demonstration of capabilities and effectiveness of Unmanned Marine Vehicles (UMVs), aerial, surface, and underwater, in monitoring and sampling the sea-ice-atmosphere interface in front of tidewater glaciers. In particular, in 2015, 2017, and 2018 (depicted in Figure 1) respectively, three campaigns were carried out in Ny-Ålesund, Svalbard Islands, to demonstrate: (i) The capability of an Unmanned Semi-Submersible Vehicle (USSV) to approach a glacier front, collecting water samples just below it; (ii) the capability of a USSV to work in cooperation with UAVs for sea surface and air column characterisation in the proximity of fronts of glaciers; and (iii) the capability of a USSV, equipped with suitable tools and instruments, to perform a repetitive sampling of the water surface as well as studying the parameters of the water and air column close to the front of glaciers.

This paper describes, from a robotic point of view, the field activity performed by CNR in the above-mentioned campaigns. The activities were supported by the logistic aids provided by Kings Bay AS and Dirigibile Italia station in Ny-Ålesund. Data sampling and sensing were carried out in the proximity of the Blomstrandbreen, Kronebreen, Kongsbreen, and Conwaybreen glaciers, in the 
Kongsfjorden, using the prototype Shark USSV (2015) and the modular reconfigurable PROTEUS ROV/AUV/USSV $(2017,2018)$ together with the OTTO UAV $(2017)$. In particular, this work discusses the advantages and the issues given by single- and multiple- vehicle operations (surface and aerial). Moreover it also points out how the lessons learnt, as far as the logistic and the operations at sea are concerned, motivated the development of light and small size robotic vehicles to be able to carry on multiple heterogeneous data acquisition and sampling devices, often ad-hoc developed. The final result was the production of a robotic tool capable of performing an efficient and reliable multi-sensor analysis in the whole column underwater-sea surface-air in the direct contact with tidewater glaciers front.

The paper is organised as follows. Section 2 introduces scientific motivations of marine robotics applications in Arctic regions and presents logistic conditions and support in the Dirigibile Italia station in $\mathrm{Ny}$-Ålesund. Section 3 describes the prototype and commercial unmanned vehicles used in the different missions. A detailed report of the campaigns, carried out in the framework of the ARCA (ARctic: present Climatic change and pAst extreme events), UVASS (Unmanned Vehicles for Autonomous Sensing and Sampling), and EXCELLABUST (Excelling Labust in Marine Robotics) projects, is given in Section 4, while a general overview of results, technological and operational approaches, and lessons learnt in the three campaigns is discussed in Section 6.

\section{Scientific and Logistical Framework}

The robotics research activities were driven by scientific interests related to the study of the Kongsfjorden atmospheric and oceanic dynamics and were subject to the constraints given by the logistical availability of the Ny-Ålesund scientific base. A short overview of the scientific motivations and of the available logistic infrastructure will facilitate the reader in understanding the context in which the activities were carried out as well as the reasons for specific technical choices and solutions.

\subsection{Scientific Motivation: The Svalbard Archipelago Environment}

Polar science is one of the most meaningful ways that humanity has got to reading the Earth's history and evaluating its future. Today the two Poles represent the thermometer of the Earth, useful in evaluating the evident impact that human beings have on the climate. For this reason research in the polar regions is not only important and relevant for the knowledge of the planet but has a direct impact on its protection, which is strictly related to everyday life with an economic and social fall out.

Regular ice ages and cycles occurring approximately every 100,000 years are paced by the cycles in the Earth's orbital mechanics but are amplified by the presence of ice and snow and today the human impact on the climate is evidently modifying the trend of these cycles. It is indeed well known that in the last 50 years, polar environments have faced a wide range of changes. Many of these changes were evident since the mid-1970s. In particular, reconstructions of past environmental changes in the Arctic [18] suggested that the variability was driving to unprecedented changes in the Arctic environment.

If $80 \%$ of the fresh water of the planet is thought to be held by polar ice with the biggest share in the AntArctic, it is evident that the study and preservation of what is collectively known as the cryosphere, the total amount of polar ice caps, continental ice sheets, glaciers, permafrost, and all the other frozen zones of our planet is important. In particular, in the Arctic system strong and inextricable interrelationships exist between its physical, chemical, biological, and social components. In this framework, the Svalbard Islands represent a border area between the Atlantic and Arctic bio-geographic as shown in Figure 2 [5]. Here the glacial input of freshwater and sediment creates environmental gradients that induce major changes in community composition [19]. The fjords system is assumed to be particularly vulnerable to climate changes and thus the Svalbard Archipelago, in the Norwegian Arctic sea, is considered suitable by scientists for investigating the phenomena related to climate changes. The retreat of tidewater glaciers front in this area has been especially pronounced in recent decades and has led to the release of huge volumes of cold and fresh water and to an accumulation of sediments near sea-ice interfaces. Notably interesting is the case of 
the Kongsfjorden, an Arctic glacial fjord located on the west coast of Svalbard $\left(7902^{\prime} 44.95^{\prime \prime} \mathrm{N}\right.$, $1134^{\prime} 57.03^{\prime \prime} \mathrm{E}$ ), where high sedimentation rates have been recorded in the past few years.

Recent results shown by [20] suggest that, as the Arctic temperature rises, the flux of glacier-derived material, and in particular subglacial run-off, will increase accordingly. This will sensibly affect the glacier-fjord discharge material. The sea-ice coverage will reduce and the photosynthesis available radiation will increase together with turbidity. This will decrease the light penetration into subsurface water, diminishing the primary production. The fluxes of water in the fjord, already modified, will progressively modify and the exchange of nutrients from the bottom waters will decrease with a reduction of biological production.

As discussed in [21], although the melt-water discharge from tidewater glaciers in the Kongsfjorden impacts the adjacent marine environment, the lack of data from close proximity to glacier fronts makes the mechanisms, through which melt-water runoff and subglacial discharge from tidewater glaciers influence marine primary production, to be still poorly understood.

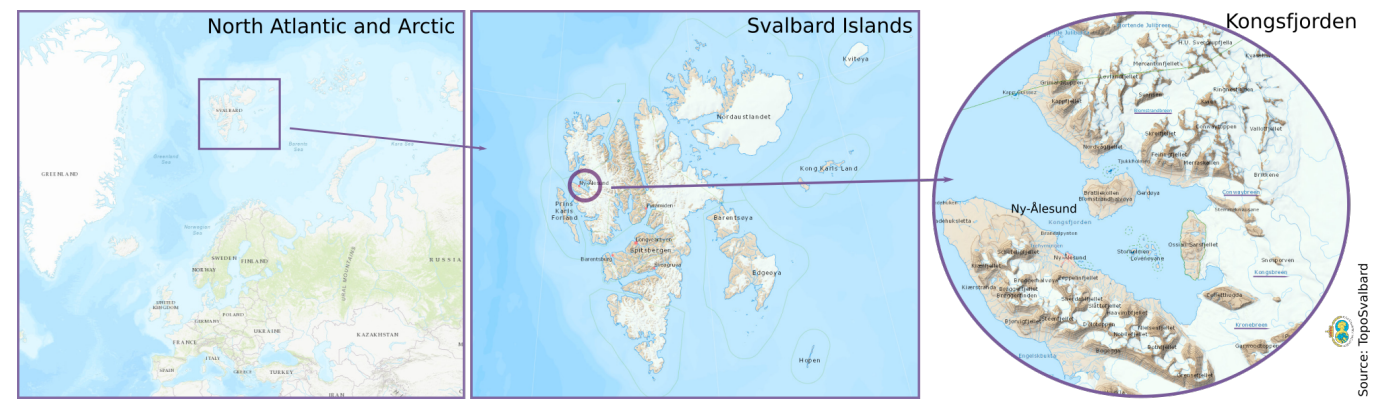

Figure 2. The location of Svalbard and Kongsfjorden.

In this situation, as well as in similar cases, direct measurements in the proximity of glacier fronts are often lacking because the possibility of sudden falls of massive ice blocks make data acquisition in these areas extremely dangerous. The navigation is even forbidden in this area due to safety reasons (see Figure 3).

Therefore, the Svalbard archipelago can serve as an optimal Arctic research environment where it is possible to follow ecological changes [22], enhanced by the presence of manifold international polar research bases settled in Ny-Ålesund. In the inner part of the Kongsfjorden, many glaciers reach the sea with marine fronts that form a high vertical wall of ice protruding above seawater. The various processes [23] contributing to Arctic amplification of climate warming link the local observations recently recorded in $\mathrm{Ny}$-Ålesund in the Kongsfjorden with processes occurring both in the Arctic and in the Northern hemispheric mid-latitudes.

The need to gain a holistic perspective to ameliorate the understanding and predictive capabilities, has became more and more clear. It is important to focus on processes and their interactions between the biosphere, geosphere, atmosphere, cryosphere, and hydrosphere. Nevertheless, even if the Arctic ocean is considered a key indicator of climate change significant gaps in data collection still remain.

The Svalbard Integrated Observing System (SIOS) [24] is present as an international observing system for long-term measurements in and around the Norwegian archipelago of Svalbard, addressing Earth System Science questions. SIOS integrates [8] existing distributed observational infrastructures and brings observations together into a coherent and integrated observational programme over a long period. 


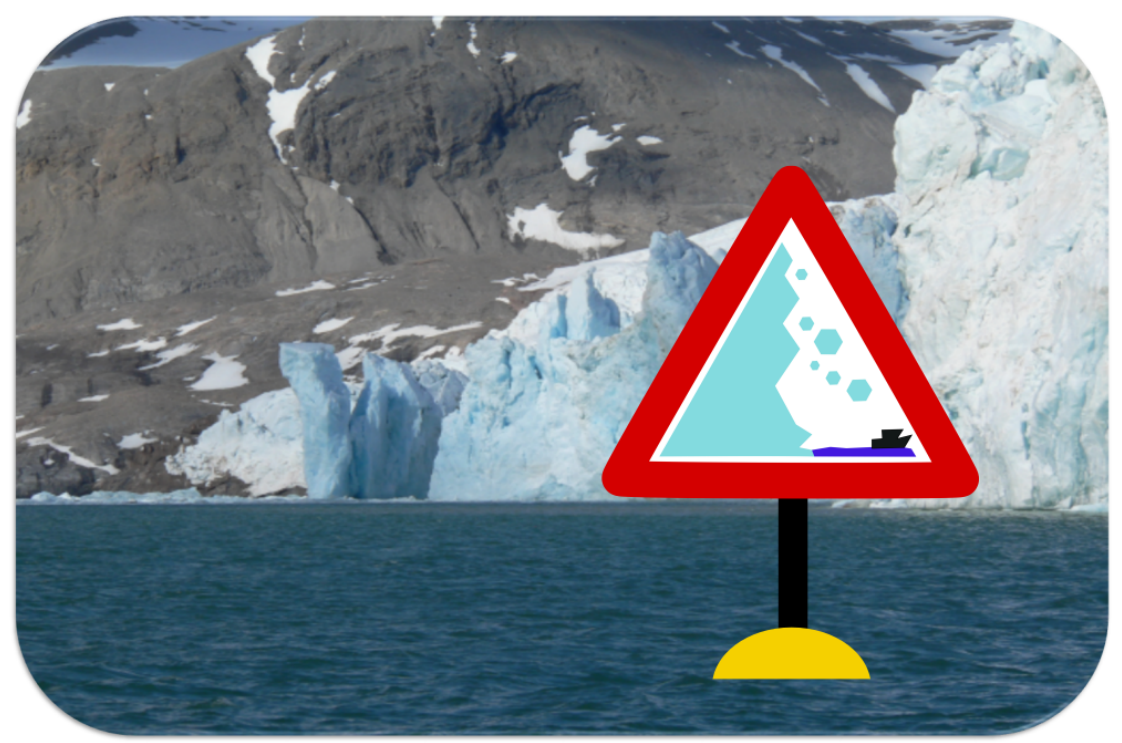

Figure 3. A picture showing the dangerous and non-navigable area in front of the Blomstrandbreen tidewater glacier.

In this framework, the use of automatic systems reported in this article initially allowed the collection of data in planktonic communities and the detection of variations occurring in water quality. This gave the possibility of performing bacteriological analyses to study the abundance and metabolism of the microbial community inhabiting the waters of Kongsfjorden in direct contact with the front of tidewater glaciers as shown in Figure 4. Moreover, the collection of the water and air's chemical parameter allowed the collection and record of same-time data in the whole column of water and partial column of air, which is also in direct contact with the glacier surface. By bringing together these different types of observations it is possible to understand how they are mutually influenced in order to have new insights on the behaviour of the processes of the Svalbard region in the Arctic Sea and in the related terrestrial system.

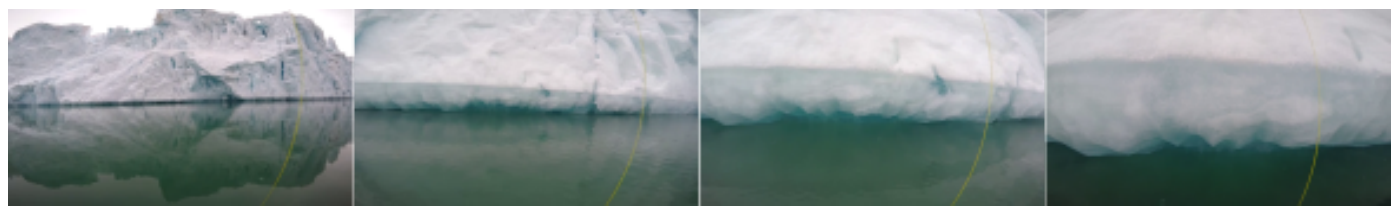

Figure 4. On-board camera view of PROTEUS Unmanned Semi-Submersible Vehicle (USSV) approaching and touching and sampling the face of the Kongsbreen glacier in Svalbard.

\subsection{Logistic Research Infrastructure}

In this section the Ny-Ålesund settlement, the Dirigibile Italia Arctic Station, and the facilities provided by Kings Bay AS are briefly described.

\subsubsection{Ny-Ålesund and Logistics}

The permanent scientific community of $\mathrm{Ny}$-Ålesund is the northernmost year-round settlement on Earth. Ny-Ålesund is situated at $78^{\circ} 55^{\prime} \mathrm{N}, 11^{\circ} 56^{\prime} \mathrm{E}$ on the west coast of Spitsbergen, the largest island in the Svalbard archipelago.

$\mathrm{Ny}$-Ålesund is a centre for international Arctic scientific research and environmental monitoring. The logistic service provides air transport, service ship handling and harbor services, power production, water supply, as well as other logistic services related to scientific activities.

Here the Italian National Research Council (CNR) manages the "Dirigibile Italia Arctic Station". The activities carried on include chemistry and physics of the atmosphere, marine biology, 
technology research, oceanography/limnology, environmental studies, human biology, and medicine. The strategic activities carried on in Ny-Ålesund by CNR [25] are integrated in a pan-Arctic observing network in order to study the complex dimensions of the Arctic regional climate system.

Reaching Ny-Ålesund requires one to fly from the Norway mainland to the administrative centre of Svalbard that is Longyearbyen $\left(78^{\circ} 13^{\prime} \mathrm{N}, 15^{\circ} 33^{\prime} \mathrm{E}\right)$. Internal flights to and from Ny-Ålesund are provided by Kings Bay AS [26], which issues all bookings and reservations.

More difficult is the shipping of material from Italy to Svalbard, as it takes almost two months. The ships that bring material to Ny-Ålesund leave just twice a month from Tromsø to Longyearbyen and once a month from Longyearbyen to Ny-Ålesund and this makes the shipping of bulky or heavy material without good organisation difficult. Moreover, the shipment of lithium ion batteries with a capacity of $>100 \mathrm{Wh}$, as those used by Shark and PROTEUS (Portable RObotic TEchnology for Unmanned Surveys), in the scope of Dangerous Goods Transport Regulations and various transport companies do not provide road transport. Therefore many specific requirements have to be respected for road or air transport [27]. Lithium ion cells and batteries must be offered for transport at a State of Charge (SoC) not exceeding $30 \%$ of their rated design capacity.

Another difficulty in operating in the Kongsfjorden is caused by the fact that Ny-Ålesund is a radio silent area within a $20 \mathrm{~km}$ radius from the centre of town ( $\mathrm{Ny}$-Ålesund Radio Silence zone) so there are radio frequency restrictions in this zone (that covers the whole Kongsfjorden) and all users of unmanned systems that use radio frequencies must adhere to strict rules. Permission from the Nkom (Norwegian Communications Authority) is obligatory for use of any frequency in the range 2-32 GHz because no frequency can interfere with ongoing scientific measurements in Ny-Ålesund. Therefore, it is important to contact Kings Bay about the frequencies that are planned to be used before going to Ny-Ålesund for the use of radio-controlled unmanned vehicles. In 2015, to avoid restrictions, as a communication link between the used robotic vehicle and its pilot station we used a Wi-Fi system based on radios working at an allowed frequency of $900 \mathrm{MHz}$. The communication bandwidth of the above-mentioned system was quite narrow and the transmission of video images was quite problematic. For this reason in 2017 and 2018 we requested and were allowed to use an upgraded radio system working at a $2.4 \mathrm{GHz}$ frequency. This was possible because we demanded the use of frequencies in the "forbidden range" but only for a limited and known period of time.

\subsubsection{MS-Teisten}

The MS Teisten is the support vessel provided by Kings Bay AS for operations in Kongsfjorden and Krossfjorden in the main season from 1st May to 30th September.

The boat, including captain, fuel, and sampling equipment, can be rented by all scientists visiting Ny-Ålesund. Five passengers in addition to the skipper on-board is the maximum capacity for sightseeing and transport.

The boat is $14 \mathrm{~m}$ in length, $4.5 \mathrm{~m}$ in breadth with a cargo space of about $4 \times 4.5 \mathrm{~m}^{2}$. The boat is provided with an extensible crane with $450 \mathrm{~m}$ of wire for $100 \mathrm{~kg}$ and $1000 \mathrm{~m}$ of wire for $1000 \mathrm{~kg}$.

The crane was used in the three CNR-INM campaigns for deploying and recovering both the Shark and the PROTEUS USSVs.

The MS Teisten is provided with a GPS and AIS system. In a 2018 campaign, an AIS was installed on-board PROTEUS to detect its position in case of loss.

During a 2017 campaign, a plywood platform (Figure 5) was installed on the stern structure of the MS Teisten to allow the landing and take off of the Otto UAV as will be illustrated in the following. 


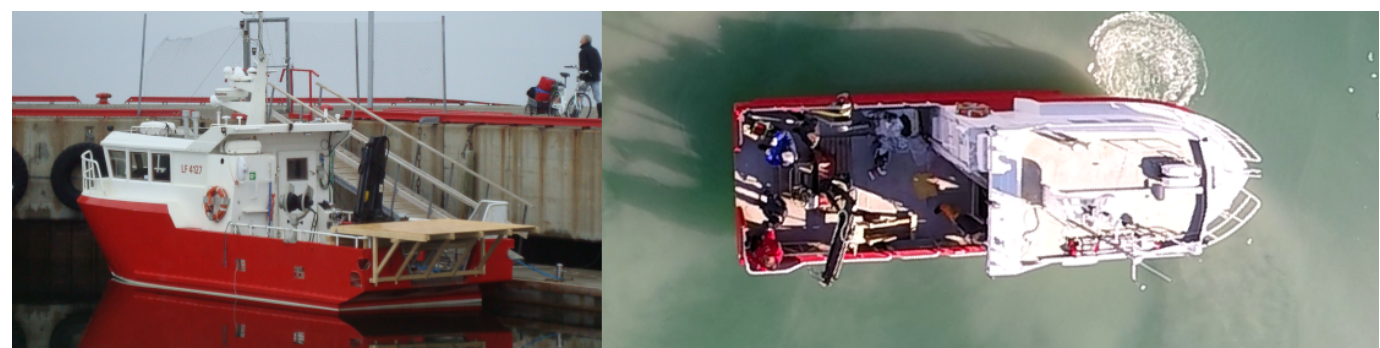

Figure 5. MS Teisten in the Ny-Ålesund harbour and in view from an aerostat.

Each year the booking of the MS Teisten should be done as early as possible. As far as the CNR-INM campaigns are concerned, the booking was carried out many months in advance.

\subsubsection{Marine Laboratory in Ny-Ålesund}

The Marine Laboratory of Kings Bay AS (Figure 6) is a common infrastructure in Ny-Ålesund for research in marine ecology, physiology, biochemistry, as well as physical sciences like oceanography, marine geology, and ice physics.

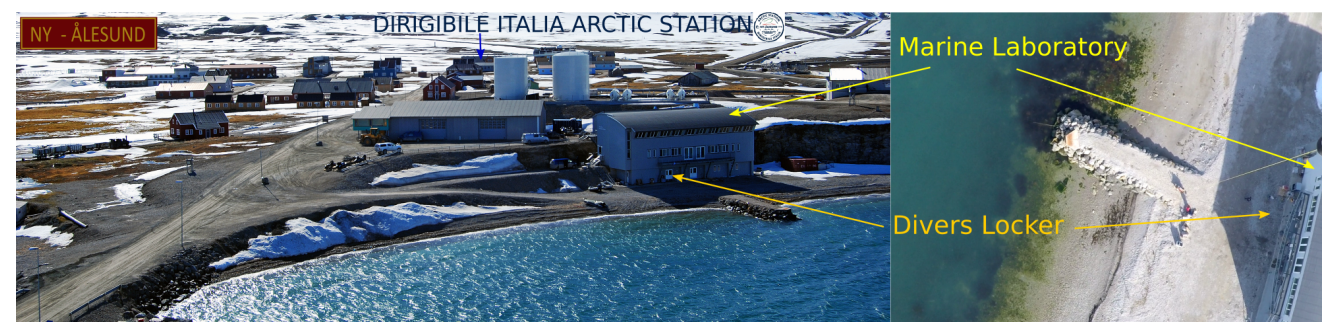

Figure 6. Ny-Ålesund and the infrastructures used by Italian National Research Council (CNR)-INstitute of Marine engineering (INM) researchers.

The laboratory is located right on a beach near Ny-Ålesund harbour with easy access to boats.

The laboratory is provided with a diver locker that is open directly to the beach where it is possible to use the whole space available for mounting/unmounting unmanned vehicles. The vicinity with the beach allows a quick test of all the equipment.

Moreover, the equipment of the Marine Laboratory allows one to sterilise the bottles used to collect water and to prepare purified and deionised water with a standard purification system for the cleaning of the probes and of the water samplers.

An analysis on the samples can be made in the dry, wet, and calibration laboratories of the Dirigibile Italia Station.

\section{Unmanned Marine Vehicles}

\subsection{Shark USSV}

Shark USSV, see Figure 7, was originally designed and developed by CNR researchers as prototype 1.0 to support the validation of cooperative robotics techniques for the recovery of emergency towing devices for distressed ships [28]. Shark USSV is a fully electric vehicle, $0.9 \mathrm{~m}$ long, $0.75 \mathrm{~m}$ wide, $0.8 \mathrm{~m}$ high, and weighs $40 \mathrm{~kg}$ in air. The vehicle, built with stainless steel, polyvinyl chloride (PVC), and closed cell foam, is equipped with four DC brushless motors coupled with 4-bladed propellers, capable of a maximum bollard pull of about $150 \mathrm{~N}$. Steering is performed by a differential revolution rate of right and left propellers. Its navigation package is constituted by a Microstrain 3DM-GX3-35 GNSS/AHRS High performance, while data acquisition and control electronics consists of a PC/104 SBC (Single Board Computer) with analog, digital, and serial I/O boards, running a GNU/Linux-based operating system (Ubuntu 12.04 server) and a real-time control application, written in $\mathrm{C}++$. Power is supplied by a pack of Lithium ions batteries, positioned in a dedicated cylindrical canister on the 
bottom of the vehicle, and guaranteeing about two hours of operations. A communication system, based on a couple of $900 \mathrm{MHz}$ WI-FI radios provides a low speed (300 kbps maximum) Ethernet link between the robot and its control station, allowing the human operator to send commands, and receive telemetry and live video up to a range of about $500 \mathrm{~m}$. Although Shark USSV guidance and control system already implemented advanced manoeuvring algorithms, due to the very difficult operating conditions of the sea near the glacier (presence of manifold small and medium size drifting icebergs), the vehicle is piloted by a human operator using the semi-automatic working mode (auto-heading and auto-speed). The floating ice block obstacles are avoided with the help of a visual feedback, provided by a camera mounted on the bow of Shark. The command console is composed of a rugged laptop with a Xubuntu 12.04 desktop OS, running a HCI (Human Computer Interface) software written in $\mathrm{C}++$ that receives and visualises in real-time the system telemetry (vehicle's plant status, sensors data, etc.), and sends commands inputted by a keyboard or joypad. Live video is displayed on a dedicated monitor.

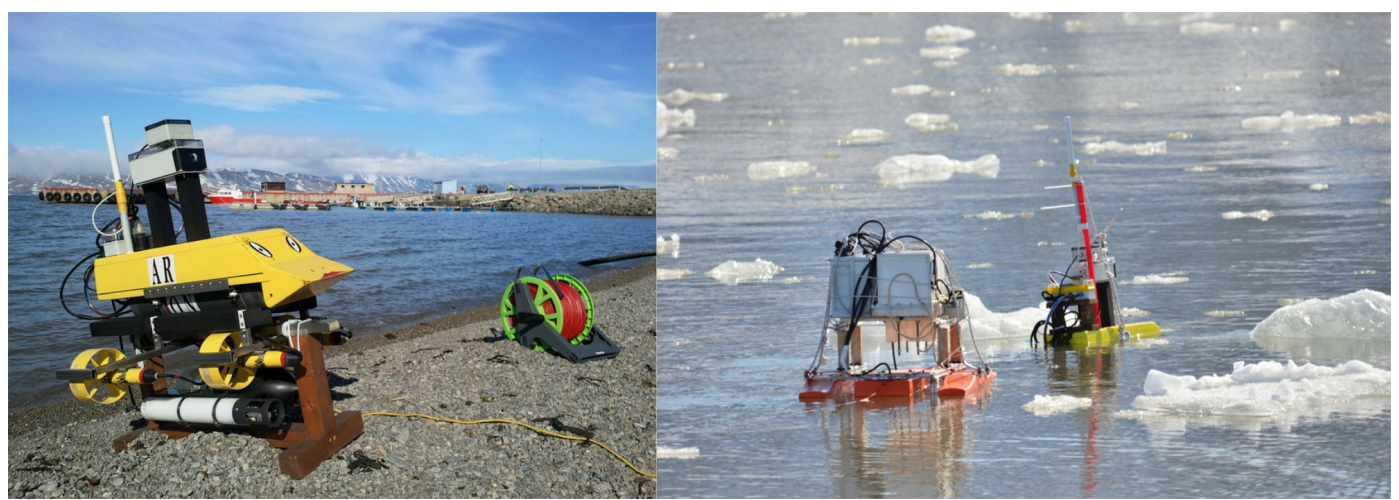

Figure 7. Shark USSV: Preliminary trials in Ny-Ålesund.

Moreover, Shark USSV is connected by means of a rope to a small towed trimaran carrying an Automatic Water Sampler (AWS), see Figure 8. A serial RS-232 communication link connects the Shark control system to the AWS, designed on the basis of the experience of CNR-IAMC researchers [29]. This link, bridged through the Wi-Fi communication channel of Shark enables the operator to remotely execute water sampling in the chosen points of interest.

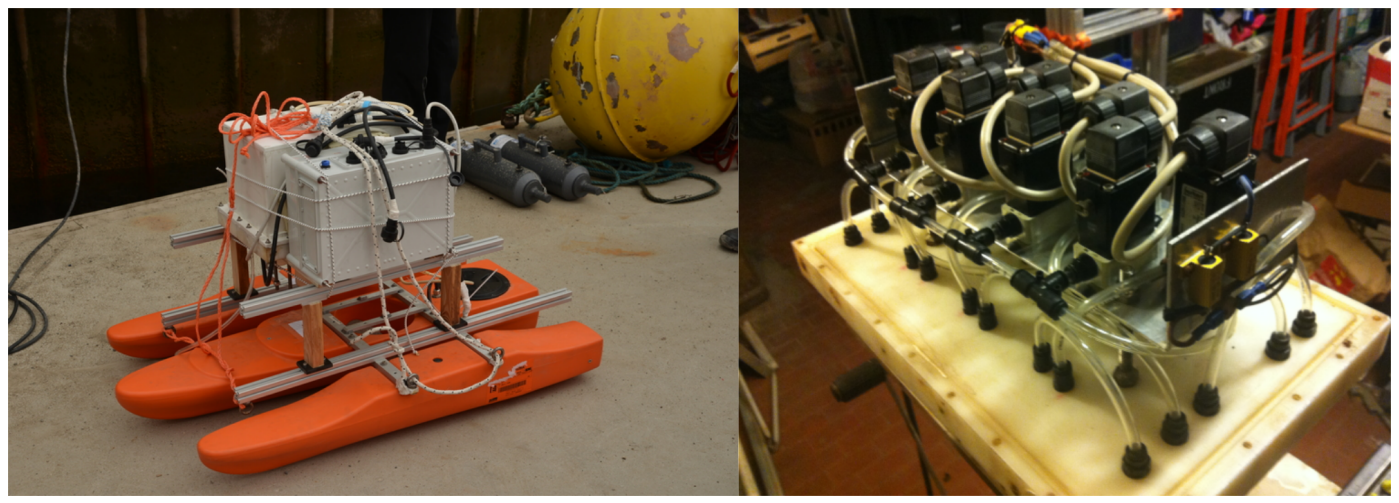

Figure 8. Towed trimaran equipped with an Autonomous Water Sampler (AWS).

\subsection{PROTEUS Hybrid ROV/USSV}

PROTEUS (Portable RObotic TEchnology for Unmanned Surveys) hybrid ROV/USSV is a fully electric vehicle that physically implements the concept of portable modular reconfigurable Unmanned Marine Vehicles, elaborated by CNR marine robotics researchers on the basis of their experience in polar applications. In particular, the project RAISE, funded by the Italian National Programme of Research in Antarctica (PNRA), where the distribution of Pleurogramma Antarctica's eggs and larvae [30] in the platelet ice was monitored with the support of a VideoRay mini-ROV adapted by the 
CNR robotics team, pointed out the need of highly modular and portable light robotic vehicles, easily transportable by helicopters and manageable by a couple of people with no cranes or similar tools. As a consequence, in the framework of the PNRA POLE project, the Portable Polar ROV (P2-ROV) was developed [31], satisfying not only requirements in terms of modularity and portability, but also an operational size and shape constraints. This led to the design of an open-frame torpedo-like vehicle suitable for the deployment through a hole in the packed ice made by a manual core drill. P2-ROV is the basis of the POP-ART concept represented in Figure 9: An open-frame torpedo-shaped ROV which is transformable into different kinds of UMVs (ROV, USSV, and AUV) by adding or removing various modules. In this framework, the prototype hybrid ROV/USSV PROTEUS was designed and built as a portable (45-70 kg weight, $1.5 \mathrm{~m}$ long, $0.35-0.5 \mathrm{~m}$ wide, and 0.35-1.5 $\mathrm{m}$ high), highly modular, and reconfigurable vehicle. It is constituted by a core body and various portable modules that can be assembled at field to compose a task-changing modular vehicle. PROTEUS core can be operated as a ROV when tethered to a mother-ship. It can also be transformed into an USSV by removing the tether cable, adding a battery pack below the vehicle, installing on its top a module composed of foam, GPS and radio communication system, and moving vertical thrusters to a horizontal surge configuration. One of the most important features of PROTEUS is the highly flexible and impact resistant frame, which is especially designed, seeking modularity, for quick installation and shifting of tools, equipment, and sensors. PROTEUS thrusters are also interchangeable, displaceable modules expressly designed by CNR personnel. In this way the vehicle can be turned into a different kind of UMV (ROV, USSV) and by connecting two USSV units with a mechanical frame, a catamaran can be obtained. Moreover, PROTEUS can be reconfigured upon each expedition according to specific needs. Thanks to its open hardware and software architectures, PROTEUS can easily be fitted on board with a number of different sensors and actuators according to the specific mission. The presence of modular elements of buoyant foam on top of the frame makes it possible to quickly balance the trim to compensate variations in the weight.

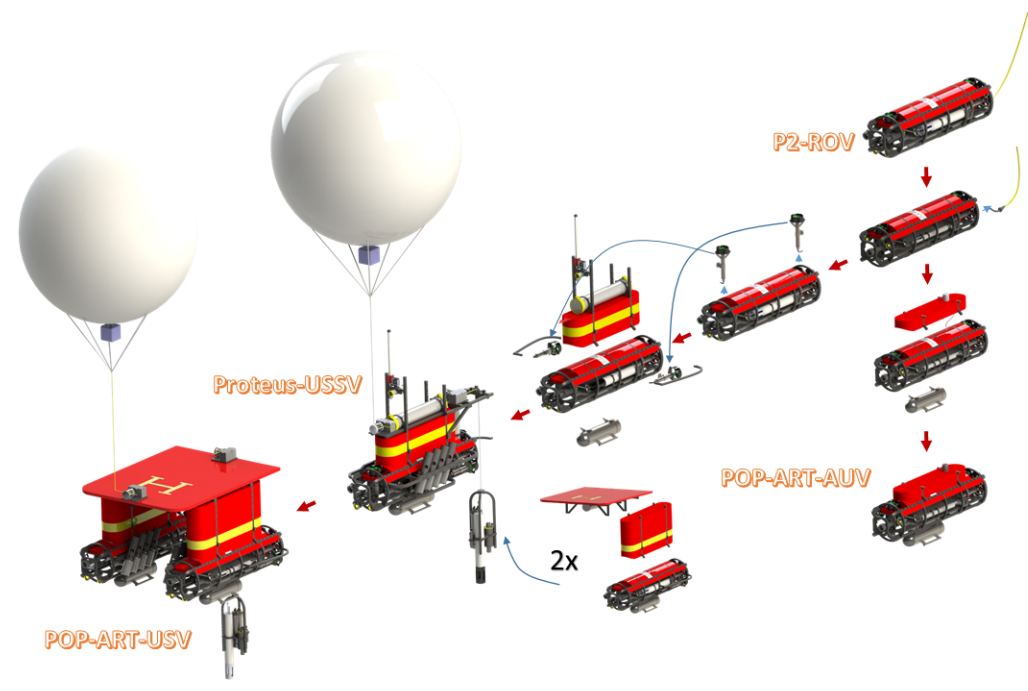

Figure 9. POP-ART (POlar Portable Autonomous Robotic Technology): modular reconfigurable UMV (Unmanned Marine Vehicle) for polar applications.

The on-board computing system is installed in a movable stainless steel canister and is based on a SBC (Single Board Computer) and three PC/104 modules providing digital, analogue, and serial $\mathrm{I} / \mathrm{O}$. The I/O channels allow the SBC to communicate and interact with the various sensors and actuators installed on the vehicle. The navigation package is constituted by a Microstrain 3DM-GX3-35 GNSS/AHRS High performance, mounted in the main canister, and a Drotek GPS0613A05 (U-Blox NEO-M8N GPS) and a Adafruit 9-DOF Absolute Orientation IMU Fusion Breakout-BNO055, installed in the surface module. DC-DC converters, motor servo-controllers, and an optic-fibre transceiver are 
installed in the main electronics canister while the power supply is demanded to a system of converters contained in an aluminium anodised canister that can be moved on the vehicle to better balance the intrinsic stability of the vehicle.

During the 2017 and 2018 campaigns, PROTEUS was mainly used in the USSV configuration shown in Figure 10 and equipped with different sensors, samplers, and tools the details of which will be provided in Sections 4.2 and 4.3 respectively.

The PROTEUS control system provides three main control modes to the pilot: Manual, semi-automatic, and automatic. In manual mode, the pilot can directly operate on motor thrusts and he/she is in charge to keep the desired heading, speed, etc. for the vehicle. In semi-automatic mode, PROTEUS control system allows one to automatically follow references of heading (auto-heading), speed (auto-speed), etc. In automatic mode, the vehicle is completely autonomous and for example, can autonomously reach and keep a desired GPS position, follow a desired path, etc. Due to the difficulties encountered operating at field in the Kongsfjorden, as a result on the one hand to the presence of a conspicuous quantity of floating ice on the stretches of sea in front of glaciers and on the other to the bad performance of the magnetic compass and GPS near the North Pole, the vehicle was often piloted in manual mode during data acquisitions.

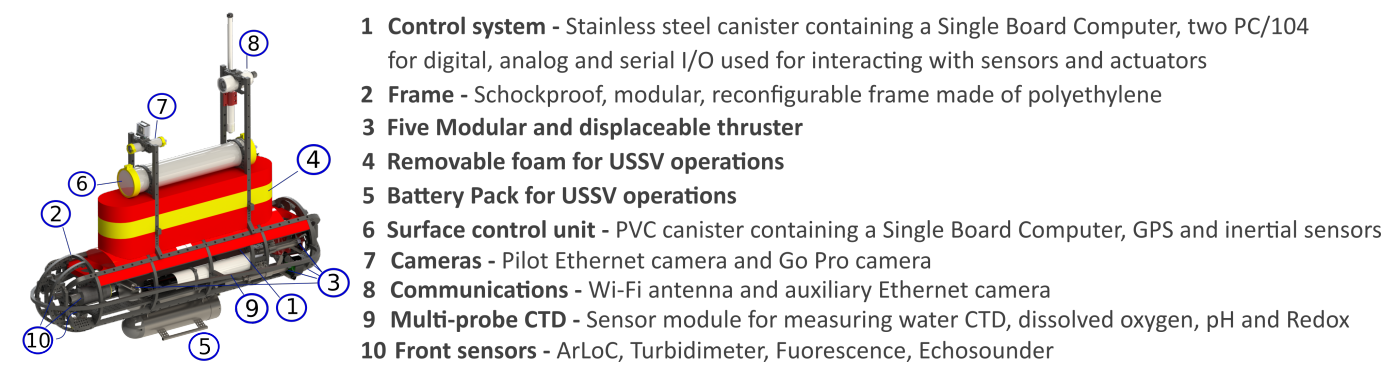

Figure 10. PROTEUS-USSV configuration in Svalbard campaigns.

The communication system of PROTEUS that permits the pilot to communicate with the robot, is composed of two different radio systems so a certain degree of redundancy for safety reasons is guaranteed. A first Wi-Fi radio system working at $2.4 \mathrm{GHz}$ allows one to send commands, receive telemetry, and a video stream from the vehicle. A second radiomodem system, working at $437 \mathrm{MHz}$, allows the user to send/receive basic and limited in size commands/telemetry data (no video is available for this narrow band channel) used for rescuing the vehicle in case the Wi-Fi link has problems. In case both the radio communications are entirely lost, a watchdog mechanism located in the robotic vehicle control system stops all actuators so that PROTEUS can be safely pulled nearer the support boat by means of a Dyneema rope.

\subsection{Commercial UAVS}

Besides USSVs, two full electric UAVs, OTTO and Splash, were also used during the surveys for different purposes. OTTO, see Figure 11, is an octocopter drone originally developed by Italdron and later adapted for polar campaigns by CNR, characterised by a high payload capacity and able to perform high quality professional flight missions in a high flight safety conditions to achieve specialised operations in critical areas. The drone was ENAC certified (S.A.P.R.) with flight termination system, rescue parachute, and an additional emergency floating buoy. Moreover it was guided with a redundant pilot system (dual pilot) with manual, automatic, and mission planning functions. In a polar mission configuration, it was equipped with various video cameras, a FLIR A35 thermal camera and an aerial multi-sensor (humidity, temperature, and air quality sensors) system, named AirQino, provided by IBIMET-CNR [32,33]. The Splash drone, see Figure 11, is a commercial waterproof quad-rotor, used to record videos and images of the coordinated operations performed by PROTEUS USSV and OTTO UAV for documentary and dissemination purposes. 

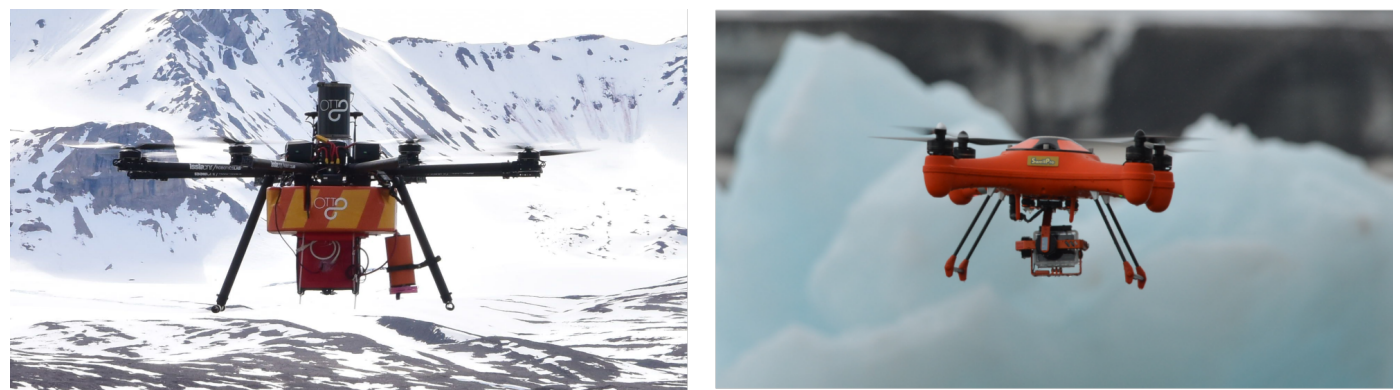

Figure 11. OTTO Unmanned Aerial Vehicle (UAV) and Splash UAV.

\section{Campaigns and Results}

The CNR marine robotics research group based in Genova, Italy, has more than 25 years of experience in the exploitation of UMVs in polar areas. After a pioneer exploration of Ross Sea benthos performed with Roby ROV in Antarctica in 1993 [34], many campaigns were carried out with Romeo ROV [35,36], and Charlie, the first USV used in Antarctica [37]. Among these activities, in 2002 in the framework of the projects e-Robot and e-Robot2 the Romeo ROV was remotely operated, through Internet and a satellite communication link, from locations in Europe when working in the Italian stations of both Terra Nova Bay, Antarctica [38], and Dirigibile Italia, Ny-Ålesund, Svalbard [39]. All these activities saw the strict collaboration between the robotics researchers and the polar scientists in order to enhance the capabilities of marine robots to perform environmental monitoring and sampling operations. On the basis of the above-mentioned campaigns, CNR research focused on designing, developing, and validating the robotic technology, and corresponding operational procedures to monitor the ice-water-atmosphere interface in proximity of tidewater glaciers.

Three scientific campaigns, presented in details in the following sub-sections, allowed one to demonstrate the feasibility of robotics technology to accomplish the task of monitoring and sampling water and atmosphere in the proximity of the fronts of glaciers, and to evaluate the performances of cooperative multi-robot systems vs. compact single robot solutions.

\subsection{ARCA Project}

The project, Arctic: Present Climatic change and past extreme events-ARCA, aimed at developing a conceptual model on the mechanism(s) behind the release of large volumes of cold and fresh water from the melting of ice caps and supported the development and testing of new technologies targeted to improve process investigation at the interfaces of the different system components, in particular hydrosphere-atmosphere and hydrosphere-cryosphere. As described above, since it is characterised by Atlantic water influx and the melting of tidal glaciers, Kongsfjorden was considered a pilot site for the evaluation of new technologies for the study of the interface between the melting glaciers front and the sea inside the Arctic fjords. Within this framework, the ARCA project supported the development of a first prototype system to perform the discrete sampling of waters in the proximity of tidewater glacier fronts. The purpose was to obtain in situ data to study the heterotrophic bacterial distribution and functional metabolism near the glacier to better understand the hydrology cycle and its consequences on the climate in the Boreal hemisphere. To this aim the prototype Shark USSV was equipped with a towed trimaran mounting an AWS (see Section 3.1). The resulting operational configuration is shown in Figure 12. 


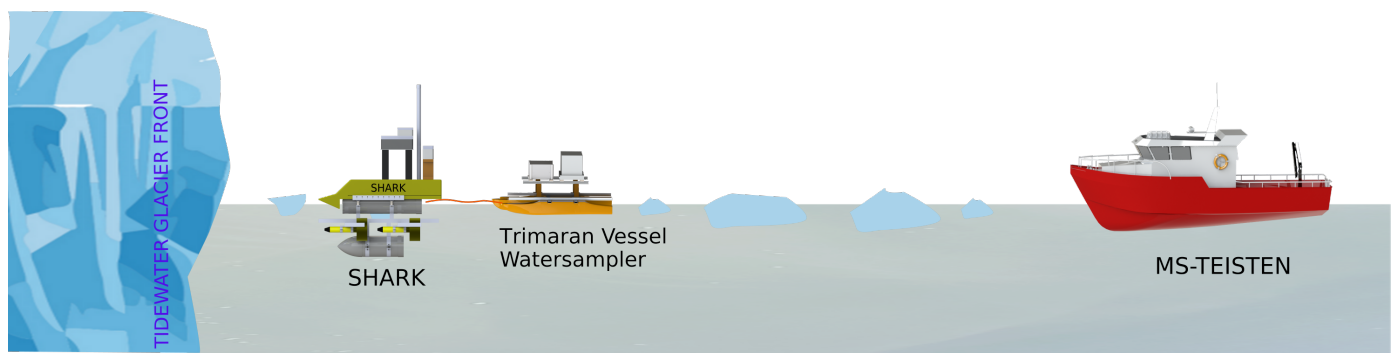

Figure 12. Arctic: Present climatic change and past extreme events (ARCA) project: Shark USSV and towed trimaran (2015).

\subsubsection{Missions}

The 2015 CNR marine robotics campaign in Ny-Ålesund was a "pilot test" for evaluating the usability of robotic tools in sampling near the front of tidewater glaciers in the Arctic environment, mainly devoted to define operational procedures and demonstrate the technical feasibility of the proposed approach. A two-day mission was performed as reported in Table 1.

On 23 June, 2015, as shown by the vehicle path graphed in Figure 13, Shark USSV reached the front of the Kronebreen glacier where, for the first time, water samples were collected. A microbiological study, carried out on the acquired samples, showed the presence of a high microbial glycolytic activity in the water collected near the Kronebreen glacier [29].

Table 1. ARCA project: Missions performed in Ny-Ålesund by Shark USSV in June 2015.

\begin{tabular}{cccc}
\hline Date & Where & \multicolumn{2}{c}{ Water Sensors (Surface) } \\
\hline 20 June 2015 & Idronaut CTD & Multisampler \\
\hline & (Area 1-78.87951,12.51246) & $\mathrm{V}$ & $\mathrm{V}$ \\
\hline 23 June 2015 & $\begin{array}{c}\text { Kronebreen } \\
\text { (Area 2-78.87543,12.55434) }\end{array}$ & $\mathrm{V}$ & $\mathrm{V}$ \\
\hline
\end{tabular}

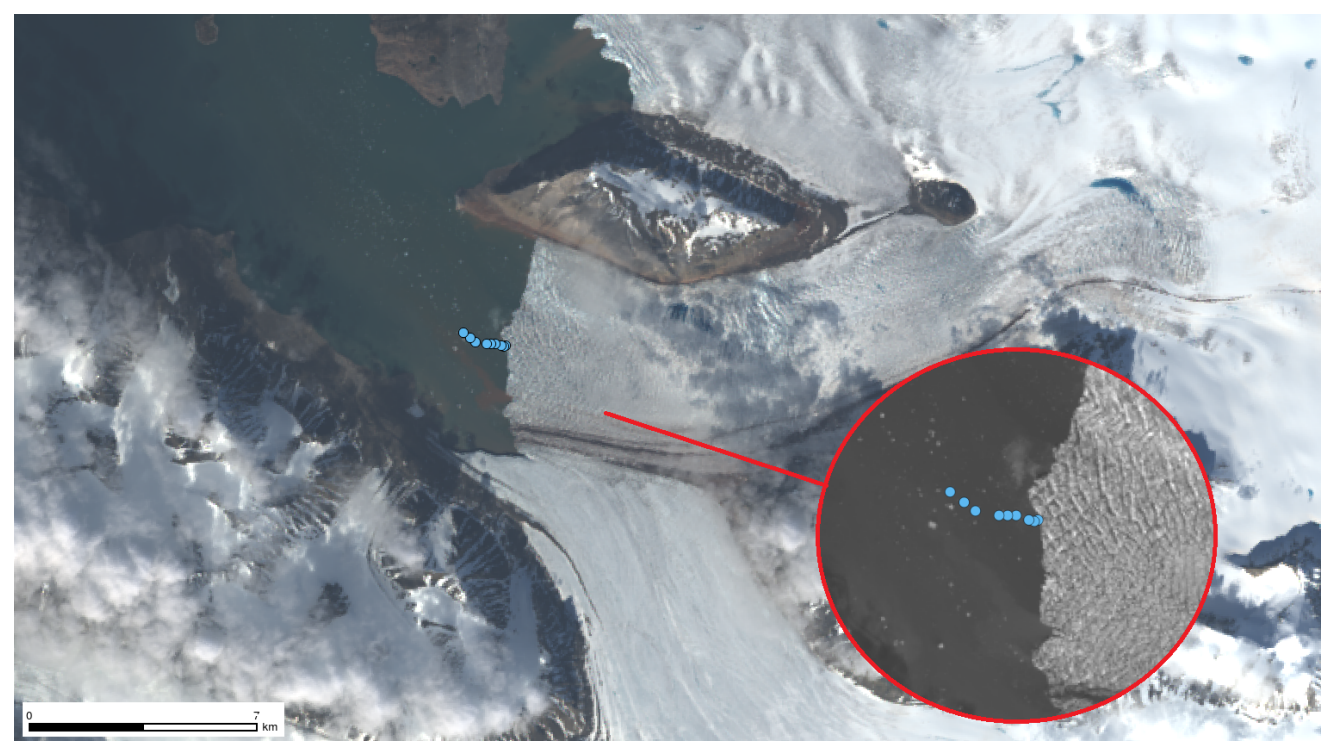

Figure 13. ARCA project: Shark USSV path to reach Kronebreen glacier front, 23 June 2015. The map of the fjord is obtained from the processing of Landsat8 data acquired on the same days of the tests.

\subsubsection{Achievements and Problems}

The objective was accomplished performing a couple of surveys as shown in Table 1, where Shark USSV, deployed by MS Teisten, was equipped with an Idronaut CTD Multiparameter probe. 
The capability of an USSV of collecting water samples and acquiring physical parameters just below the front of a tidewater glacier was demonstrated by the Shark+AWS system (see Figure 7) approaching the Kronebreen glacier front in June 2015.

The Shark+AWS system demonstrated unquestionable advantages: (i) Real-time or near real-time acquisition of physical, chemical, and biological data series; (ii) capability of avoiding the presence of manifold (small and medium) drifting icebergs obstructing the passage to the glacier; (iii) protecting the operators from falling off ice blocks that can be directly or indirectly (due to the produced waves) dangerous; and (iv) the use of small and portable tools is suitable in remote areas.

No particular technical issues were encountered during the mission. The Shark USSV was able, in calm waters and favourable weather conditions, to perform the requested sampling and to move in the middle of practically still bergy bits without any problem. The absence of currents (and wind), as explained later in this paper, was a key factor for the success of the missions since no bergy bits were dragged by currents.

A first useful indication for future missions was that a robotic vehicle in USSV configuration was very suitable for operating in waters with the presence of floating pieces of ice. This was because its semi-submersed hull allowed for good stability and to easily push aside the blocks of ice from below the surface, ergo guaranteeing a good navigation, particularly in case of collision. A second suggestion was that to have a redundant propulsion system (i.e., having on board PROTEUS more motors than those strictly necessary to perform the required movements) was a very useful feature for being able to safely return at the support boat also in presence of a motor fault.

\subsection{UVASS Project}

In 2017, from 13 June to 26 June, a second scientific campaign [40] was carried out in cooperation with researchers from other institutes of the National Research Council (IAMC, ISMAR, ISAC, IBIMET) and Tuscia University, to evaluate the capability of robotic tools to monitor sea-ice-atmosphere interface close to the marine front of tidewater glaciers. The scientific goal was that of improving the understanding of chemical, physical, biological, and meteorological phenomena occurring in this specific area.

From a robotics perspective, the project Unmanned Vehicles for Autonomous Sensing and Sampling-UVASS tested and evaluated an operational solution involving a fleet of heterogeneous UxVs, namely PROTEUS USSV towing a trimaran transporting AWS, OTTO, and Splash UAVs. A custom plywood platform $(2.5 \times 2.5 \mathrm{~m})$ was mounted on the stern of the MS Teisten for UAVs take off and landing. The resulting operational configuration is shown in Figure 14.

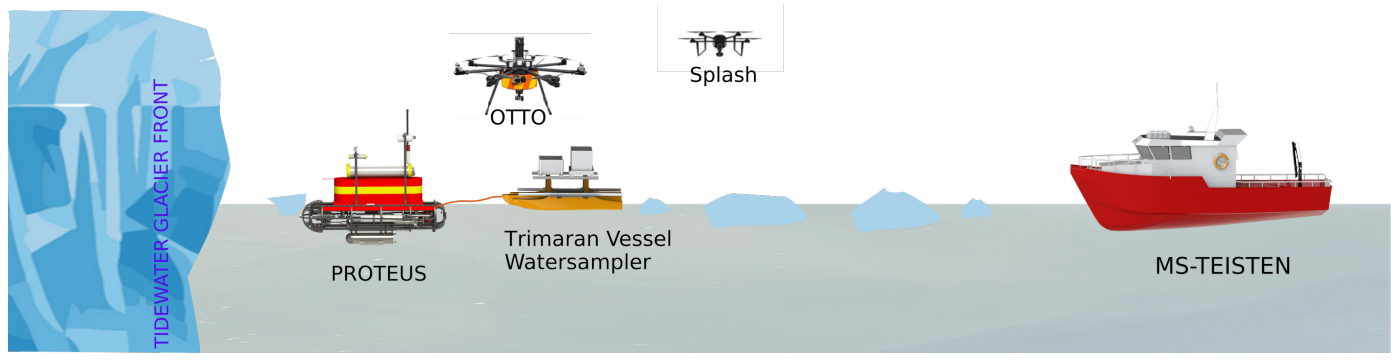

Figure 14. UVASS project: Fleet of heterogeneous UMVs (2017).

The goal of the campaign was the sea surface and air column characterisation in the proximity of the fronts of glaciers by using an USSV in cooperation with Unmanned Aerial Vehicles.

The USSV PROTEUS was equipped with the following sensing/sampling package: Underwater video-camera; led lights; GoPro camera; Tritech Micron echosounder for acquiring bathymetric data; Idronaut Ocean Seven 305 CTD multiprobe sensor for acquiring water physical parameters; small prototype sensor for measuring pressure, temperature, and fluorescence of chlorophyll named ArLoC, developed by Tuscia University [41,42]; and Turner Cyclops-7 turbidity sensor. All these sensors 
were synchronised and geolocalised thanks to real-time integration with the telemetry of PROTEUS. Wi-Fi radio connection with the remote station aboard MS Teisten allowed the scientific end-user to access data in real time and modify the sampling area according to sampling requirements and performance. Due to the need for acquiring a huge and spread amount of data a small trimaran vessel was towed by PROTEUS during its surveys Figure 15. This trailer was used to host particularly heavy or bulky sensors i.e., an automatic water multi-sampler provided by IAMC-CNR for the study of microbial biomass and bacteria respiratory activity, a plankton multi-sampler, and a Seabird SBE19plus v2 multiprobe sensor, provided by ISMAR-CNR, for performing water data sensing.

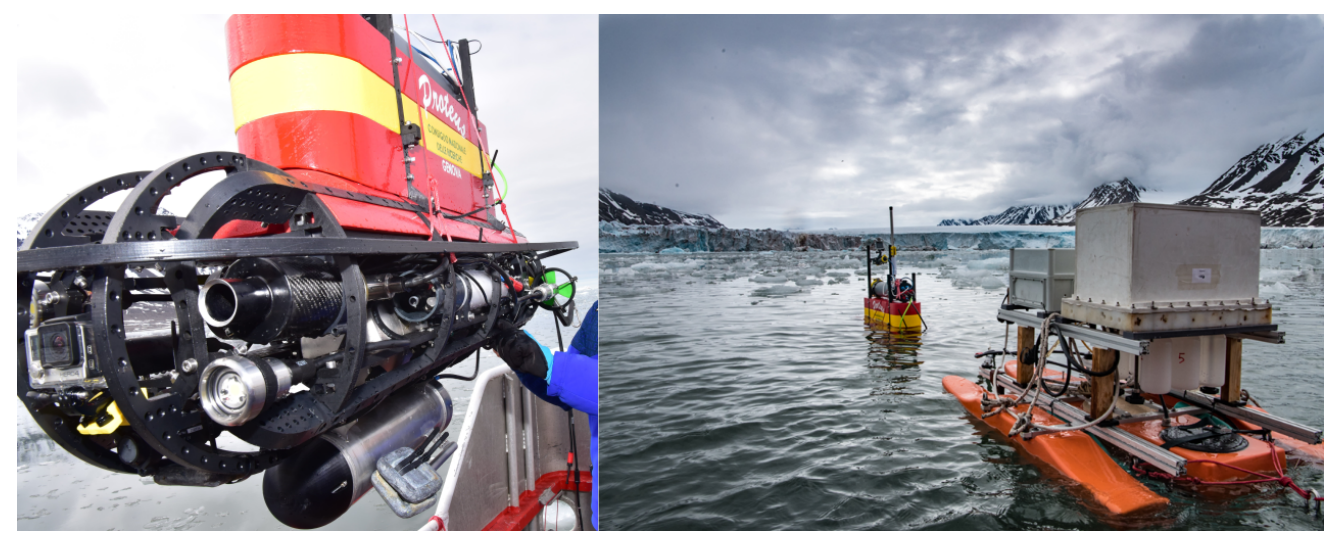

Figure 15. The 2017 campaign: PROTEUS (left) and PROTEUS towing the Trimaran vessel (right).

PROTEUS USSV, as well as OTTO and Splash UAVs, were remotely operated by personnel on-board MS Teisten, which remained at a safe distance of about $500 \mathrm{~m}$, from the glacier front.

During this campaign the only safety measure adopted for the marine vehicle was the use of a Dyneema rope to recover the vehicle in case of a sudden fall of ice on it.

\subsubsection{Missions}

Operations were performed in the stretch of sea facing two distinct glaciers in the Kongsfjorden, i.e., Kronebreen and Blomstrandbreen. The missions carried out in the 2017 campaign are reported in Table 2.

The changes occurring near the front of the glacier comprise of the ice melting and transfer of water from land to the fjord resulting in variations in temperature, salinity, and turbidity of the nearby water masses that can affect the marine ecosystem and possibly modify the biodiversity of the area. To capture parameter variations with respect to the distance, the robot moved along paths almost perpendicular to the glacier fronts, as shown in Figure 16, where the results of the vehicle motion in two different mission sets is reported.

Table 2. UVASS project: Missions performed in Kongsfjorden by the UMV fleet in June 2017.

\begin{tabular}{|c|c|c|c|c|c|c|c|c|}
\hline \multirow[t]{2}{*}{ Date } & \multirow[t]{2}{*}{ Time } & \multirow[t]{2}{*}{ Where } & \multicolumn{5}{|c|}{ Water Sensors (Surface) } & \multirow{2}{*}{$\begin{array}{c}\text { Air Sensor } \\
\text { Airqino }\end{array}$} \\
\hline & & & $\begin{array}{l}\text { Idronaut } \\
\text { CTD (105) }\end{array}$ & $\begin{array}{l}\text { TFLAP } \\
\text { (ArLoC) }\end{array}$ & $\begin{array}{l}\text { Seabird } \\
\text { CTD }\end{array}$ & $\begin{array}{c}\text { Turner } \\
\text { Turbidimeter }\end{array}$ & $\begin{array}{c}\text { Water } \\
\text { Sampler }\end{array}$ & \\
\hline 18 June 2017 & $16: 44$ & $\begin{array}{l}\text { Ny Alesund Harbour } \\
(78.92913,11.94199)\end{array}$ & V & & & $\mathrm{V}$ & & \\
\hline 18 June 2017 & 18:02 & Ny Alesund Harbour & $\mathrm{V}$ & $\mathrm{V}$ & & $\mathrm{V}$ & & \\
\hline 20 June 2017 & $10: 20$ & Ny Alesund Harbour & V & $\mathrm{V}$ & & $\mathrm{V}$ & & \\
\hline 20 June 2017 & $17: 11$ & Ny Alesund Harbour & $\mathrm{V}$ & $\mathrm{V}$ & & $\mathrm{V}$ & & \\
\hline 22 June 2017 & 18:04 & Ny Alesund Harbour & $\mathrm{V}$ & V & & $\mathrm{V}$ & & \\
\hline 19 June 2017 & 11:01 & $\begin{array}{c}\text { Kronebreen } \\
\text { (Area 1-78.87053,12.55349) }\end{array}$ & V & & & & & \\
\hline 19 June 2017 & $11: 40$ & Kronebreen (Area 1) & $\mathrm{V}$ & & & $\mathrm{V}$ & & \\
\hline 19 June 2017 & $11: 42$ & Kronebreen (Area 1) & $\mathrm{V}$ & $\mathrm{V}$ & & $\mathrm{V}$ & & \\
\hline
\end{tabular}


Table 2. Cont

\begin{tabular}{|c|c|c|c|c|c|c|c|c|}
\hline \multirow[t]{2}{*}{ Date } & \multirow[t]{2}{*}{ Time } & \multirow[t]{2}{*}{ Where } & \multicolumn{5}{|c|}{ Water Sensors (Surface) } & \multirow{2}{*}{$\begin{array}{c}\text { Air Sensor } \\
\text { Airqino }\end{array}$} \\
\hline & & & $\begin{array}{l}\text { Idronaut } \\
\text { CTD (105) }\end{array}$ & $\begin{array}{l}\text { TFLAP } \\
\text { (ArLoC) }\end{array}$ & $\begin{array}{l}\text { Seabird } \\
\text { CTD }\end{array}$ & $\begin{array}{c}\text { Turner } \\
\text { Turbidimeter }\end{array}$ & $\begin{array}{l}\text { Water } \\
\text { Sampler }\end{array}$ & \\
\hline 19 June 2017 & $14: 55$ & $\begin{array}{c}\text { Kronebreen } \\
\text { (Area 2-78.86237,12.56734) }\end{array}$ & $\mathrm{V}$ & & & V & & \\
\hline 19 June 2017 & $14: 56$ & Kronebreen (Area 2) & $\mathrm{V}$ & V & & V & & \\
\hline 19 June 2017 & $15: 07$ & Kronebreen (Area 2) & $\mathrm{V}$ & V & & $\mathrm{V}$ & & \\
\hline 19 June 2017 & $15: 12$ & Kronebreen (Area 2) & $\mathrm{V}$ & V & & V & & \\
\hline 21 June 2017 & 11:05 & $\begin{array}{l}\text { Bloomstrandbreen } \\
(79.01761,12.16775)\end{array}$ & V & & & V & $\mathrm{V}$ & V \\
\hline 21 June 2017 & $11: 11$ & Bloomstrandbreen & $\mathrm{V}$ & $\mathrm{V}$ & & V & V & V \\
\hline 21 June 2017 & $13: 29$ & Bloomstrandbreen & $\mathrm{V}$ & V & & V & $\mathrm{V}$ & $\mathrm{V}$ \\
\hline 23 June 2017 & $10: 44$ & Bloomstrandbreen & $\mathrm{V}$ & V & & V & $\mathrm{V}$ & $\mathrm{V}$ \\
\hline 23 June 2017 & $11: 10$ & Bloomstrandbreen & $\mathrm{V}$ & V & $\mathrm{V}$ & $\mathrm{V}$ & $\mathrm{V}$ & $\mathrm{V}$ \\
\hline 23 June 2017 & $12: 23$ & Bloomstrandbreen & $\mathrm{V}$ & & $\mathrm{V}$ & V & $\mathrm{V}$ & $\mathrm{V}$ \\
\hline 23 June 2017 & $13: 18$ & Bloomstrandbreen & $\mathrm{V}$ & & & V & $\mathrm{V}$ & $\mathrm{V}$ \\
\hline 23 June 2017 & $13: 30$ & Bloomstrandbreen & $\mathrm{V}$ & V & & V & $\mathrm{V}$ & $\mathrm{V}$ \\
\hline 23 June 2017 & $13: 33$ & Bloomstrandbreen & $\mathrm{V}$ & V & $\mathrm{V}$ & V & $\mathrm{V}$ & V \\
\hline 23 June 2017 & $15: 17$ & Bloomstrandbreen & $\mathrm{V}$ & V & $\mathrm{V}$ & V & $\mathrm{V}$ & $\mathrm{V}$ \\
\hline 23 June 2017 & $15: 35$ & Bloomstrandbreen & $\mathrm{V}$ & V & $\mathrm{V}$ & V & $\mathrm{V}$ & $\mathrm{V}$ \\
\hline
\end{tabular}

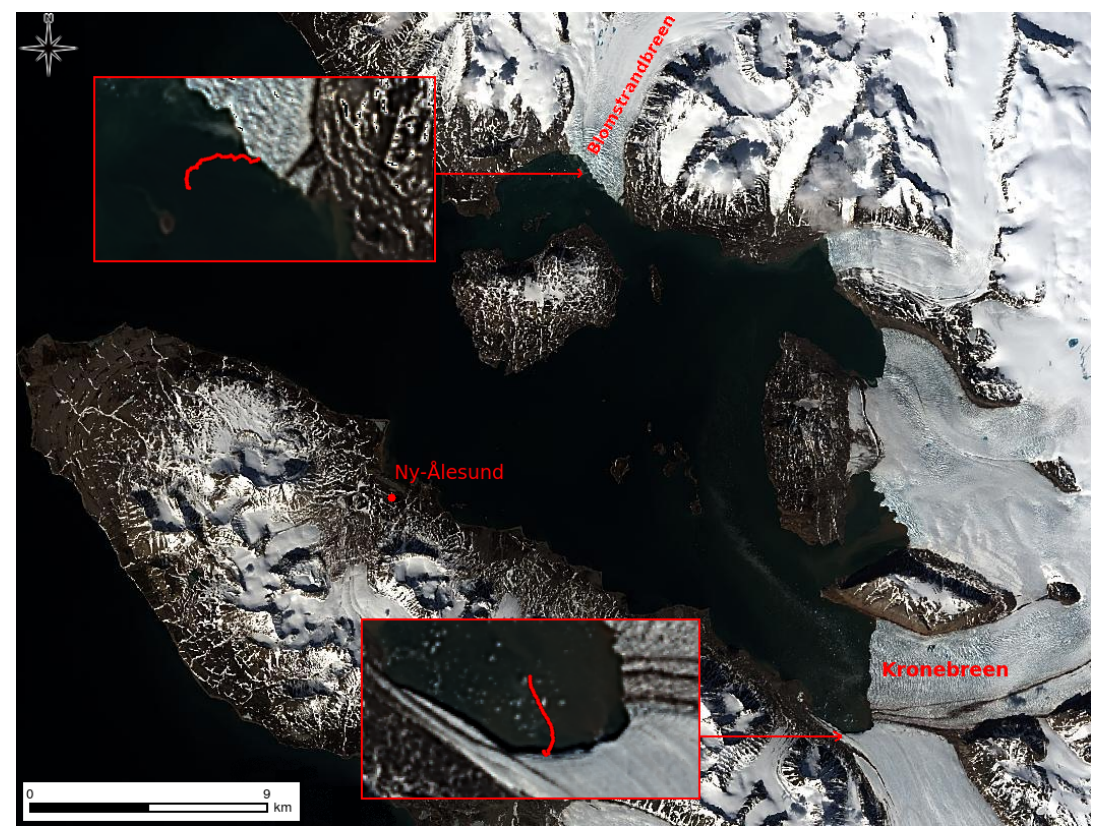

Figure 16. UVASS project: Map of the Kongsfjorden area obtained from the processing of Landsat8 data acquired in the same days in which the tests took place. In the boxes the GPS trajectories followed by PROTEUS during two missions are shown.

\section{Kronebreen Glacier Sampling}

The first set of sampling and monitoring here reported was acquired in front of the Kronebreen glacier, the same place where the pilot test was performed with Shark USSV in 2015. The glacier is located at the head of the Kongsfjorden. The sampling was carried out using only PROTEUS USSV and its towed trimaran.

As shown later, the sampling in front of the Kronebreen was limited by the presence of an enormous number of bergy bits and growlers, which modified the strategy of sampling.

\section{Blomstrandbreen Glacier Sampling}

The second set of sampling and monitoring was acquired in front of the Blomstrandbreen glacier, located in the north-east area of the Kongsfjorden (see Figure 16). This is an area affected not only by the introduction of fresh water from the melting glacier but also by the Atlantic currents that come 
from the north [5]. This area is therefore particularly interesting from the climatic changes point of view and suitable for the sampling of environmental parameters. In particular, recently, the circulation in the fjord has substantially been modified by the opening of the channel between land, glacier, and the island named Blomstrandhalvøya.

For these reasons this glacier was chosen for the combined operation with the autonomous marine vehicle PROTEUS (for the characterisation of the water) and the aerial drone OTTO (for the characterisation of the air column). The Splash drone was also used for collecting images and videos for documentary purposes. In Figure 17, the three robots operating in front of the glacier are shown.

PROTEUS was equipped with the full set of sensors and samplers listed above. During the campaign, sets of eight $500 \mathrm{~mL}$ bottles per mission were collected and numerous parameters were simultaneously recorded in water: Conductivity, temperature, depth, $\mathrm{pH}$, Eh, oxygen with the CTD, depth, temperature, chlorophyll a1, chlorophyll a2 using a multi-probe sensor, fluorescence, and turbidity. The trends of temperature, salinity, conductivity, and turbidity are shown in Figure 18 as a function of distance from the front of the glacier.

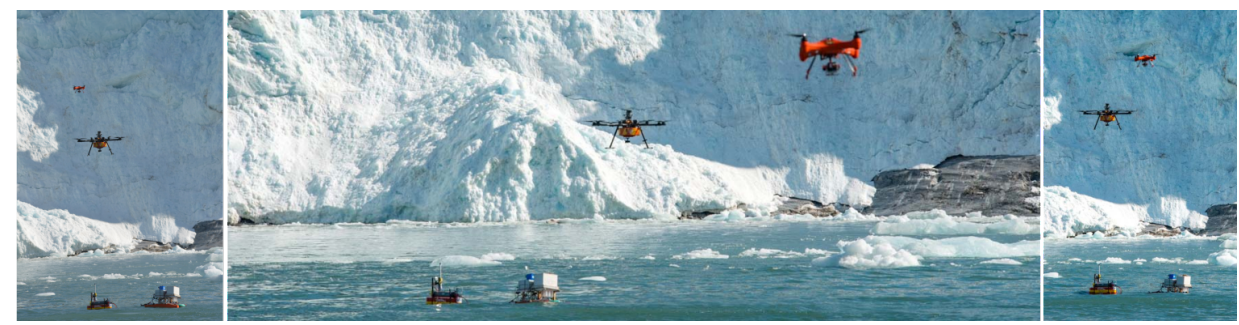

Figure 17. PROTEUS, OTTO and Splash unmanned vehicles operating near the Blomstrandbreen glacier.
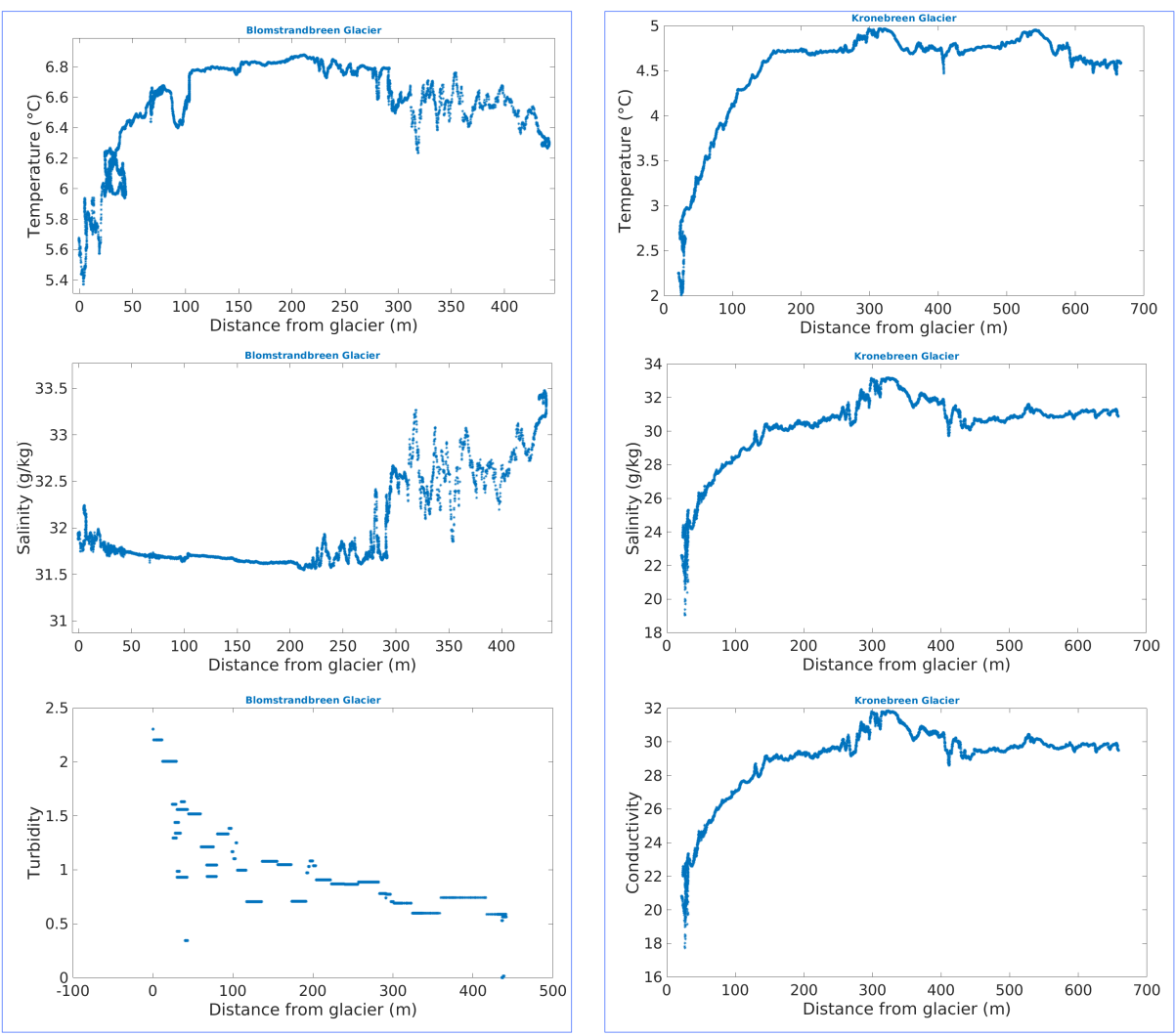

Figure 18. Trend of different water parameters as a function of the distance from the front of two glaciers (Blomstrandbreen left side and Kronebreen right side) acquired by CTD sensors. 
At the same time, the OTTO UAV performed several missions, some equipped with the air quality sensors AirQino and others with the FLIR thermocamera. In the first configuration, OTTO used the various sensors mounted on-board to acquire data allowing one to reconstruct the characteristics of the air column overlying the area inspected by PROTEUS and collected pictures and videos of the area. In the second configuration, OTTO not only collected pictures and videos of the area but also obtained a thermal pattern of the area in order to study possible correlations between data coming from air measurements and data coming from the CTD mounted on-board PROTEUS.

\subsubsection{Achievements and Problems}

The first important issue related to the 2017 campaign was the shipment of the material. Actually, when the robotic team arrived in Ny-Ålesund, it was obliged to re-build a part of the electronic core of the vehicle. The damages to the vehicle were caused by the vibrations, jumps, and bumps that the transporting box was subject to. The shipment took more than two month to reach Ny-Ålesund and this had undoubtedly affected the good state of the vehicle. This was an important point to take into consideration for future missions and in 2018 the electronic core was shipped in a separate and more dampened box. Even if this aspect limited the number of surveys performed and did not affect the results obtained in the campaign. Figures 18-20 show some examples of data collected near Kronebreen and Blomstrandbreen glaciers and some results of the analysis were presented in a series of works: [43-49].

As shown in Figure 18 (left Blomstrandbreen, right Kronebreen), the measurements carried out in high-risk areas where navigation is forbidden, confirmed the expected trend: Water temperature and salinity increased with the distance from the front of the glacier, while turbidity decreased. This is due to the fact that near the front of the glacier there are inputs of fresh water coming from melting and calving events.

The acquired samples were analysed for nutrients, organic matter, and its utilisation by microbial activity, using enzymatic activity techniques. Microbiologic analysis were used to depict differences in the microbial catabolic potential. Variations in organic matter distribution and in the functional diversity of microbial assemblages were observed. Freshwater runoff from ice melting was found to increase the amount of terrestrial organic matter to the fjord and microbial processes allowed organic matter decomposition. On the other hand, viral and prokaryotic abundances were significantly correlated with each other and their spatial distributions resulted to be not affected by the presence of the glacier. A low viruses abundance was found compared to the other marine ecosystems and it might be explained by the adsorption on particles. High nutrient concentrations were detected but they appeared to be not linked to microbial patterns [44].

Moreover two 'state-of-the-art' probes, Idronaut 305 plus and SBE-16, together with the ARLoc low-cost probe were installed onboard PROTEUS and allowed the acquisition of surface water temperature, conductivity, dissolved oxygen, chlorophyll a, fluorescence, and turbidity. These data allowed one to make a comparison between traditional and innovative probes. The results highlight a high biomass concentration in proximity of the glacier front (featuring colder water masses), thus confirming the influence of ice melting on phytoplankton bloom. At the same time, this test underlined the capacity of the PROTEUS vehicle to detect microscale ecological processes in extreme environments, where natural hazards (e.g., icebergs, falling masses of ice, etc.) hinder normal sampling activities. The study of these phenomena is of fundamental importance in increasing our knowledge of global warming process, which directly affect the ice melting. In turn, this leads to an increase in continental inputs to surface waters, resulting in phytoplankton growth.

As far as the OTTO UAV is considered, issues were encountered in the calibration of the compass: Various attempts were done but it was impossible to calibrate the compass in an acceptable way. This problem was due to proximity to the magnetic North Pole which influences the behaviour of the compass. Due to this problem and to meet the safety requirements at the same time, the two pilots of the drone flow in a complete manual and visual way. 
Examples of images acquired by the thermal camera mounted on-board OTTO UAV are shown in Figure 19: On the left there is a grey scale thermal image (ice is white while water is grey) and on the right there is the same image but in false colour scale, showing the temperature range obtained from the raw data of the FLIR A35 thermal camera. From the thermal images it is possible to retrieve an indication of the trajectories followed by the floating ice and consequently of the direction of the currents present in the surface water layer.

An analysis of the data related to the air column gave information on atmospheric chemical composition in the Arctic area. The AirQino, equipped with low-cost and low-weight but high-resolution sensors, provided measurements of meteorological parameters of relative humidity, temperature, and pollutant/species concentrations: $\mathrm{CO}, \mathrm{CO}_{2}, \mathrm{O}_{3}$, and $\mathrm{NO}_{2}$. The flown profile highlighted an expected decrease in $\mathrm{CO}_{2}$ with altitude reaching background values consistent with the recent increase of concentration of the above mentioned gas in the Arctic due to climate changes [48].
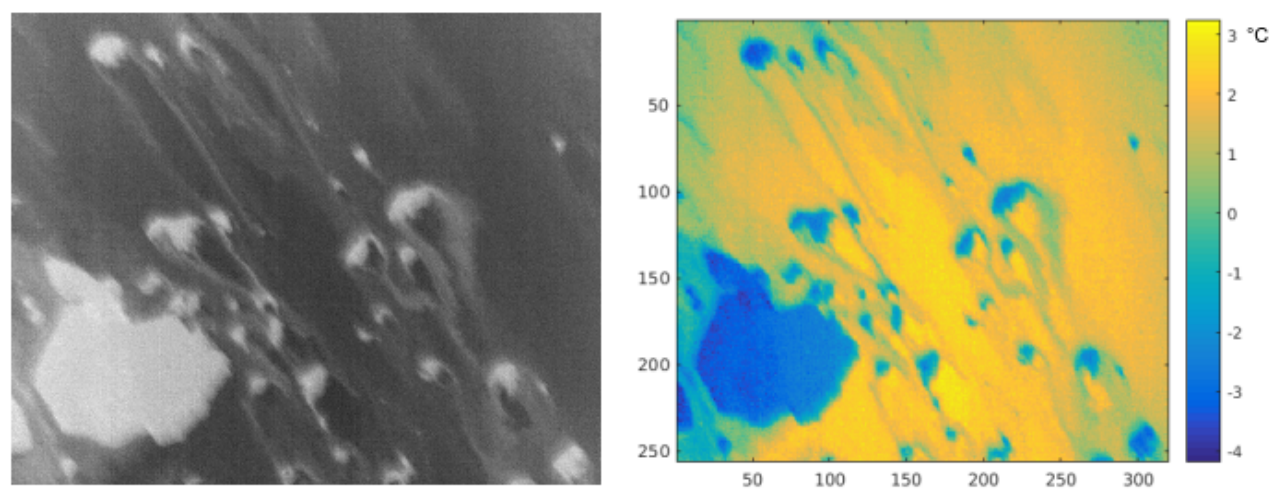

Figure 19. Thermal image obtained with FLIR A35 camera mounted on OTTO UAV (greyscale on the (left), false colours on the (right)).

Temperature and humidity sensors were calibrated against the Climate Change Tower in Ny-Ålesund, while the chemistry sensors were calibrated against reference high-cost instruments (HORIBA gas analysers). The data collected during the campaign complemented surface data from the camera giving some information on atmospheric chemical composition. An example of $\mathrm{CO}_{2}$ distribution as a function of the altitude of the OTTO drone is shown in Figure 20.

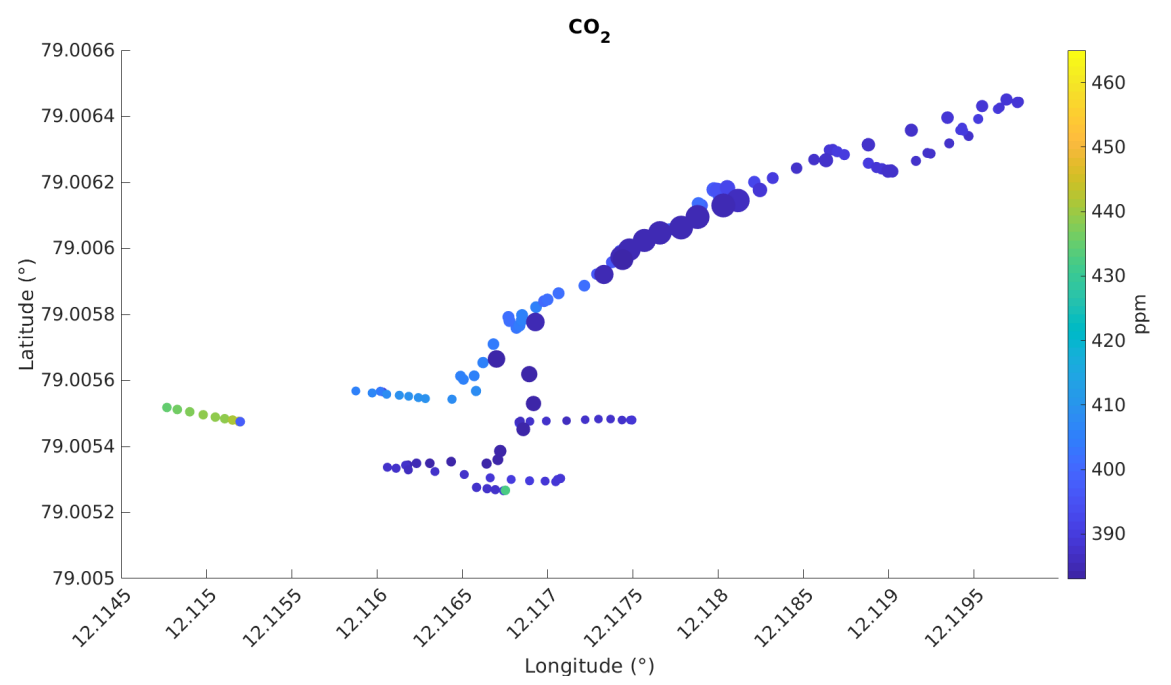

Figure 20. The figure shows a stretch covered by OTTO where the colours of the circles represent $\mathrm{CO}_{2}$ concentrations (in ppm, colour-bar on the right) and the sizes of the circles are scaled on the UAV altitude (bigger circles indicating higher altitudes). As shown, bigger circles tend to correspond to lower $\mathrm{CO}_{2}$ values. The height goes from $2 \mathrm{~m}$ (smaller circles) to $62 \mathrm{~m}$ (bigger circles). 
During the UVASS campaign, the use of the towed multisampler showed its limits. Whereas the campaign was successfully completed and the device itself always worked in the proper manner, the towing of the trimaran resulted to be an obstacle for the sampling. When the ice calving happens, the area in front of the tidewater glacier is often covered by floating ice debris (icebergs and growlers) that obstruct the passage for the vehicle. In these conditions, the towing rope is an obstacle to movement and the trimaran towed by PROTEUS can get trapped in the ice as shown in Figure 21. Even greater problems were generated by a safety connection between the vehicle and the mother ship made via a thin Dyneema cable (6 $\mathrm{mm}$ diameter). Since the cable was completely trapped between the floating ice blocks, preventing the vehicle from manoeuvring, it was necessary to cut it. The Dyneema cable was considered a safety connection to recover the vehicle in case of a sudden fall of ice on it but it could become a problem for the mission accomplishment in case of huge drifting of ice.

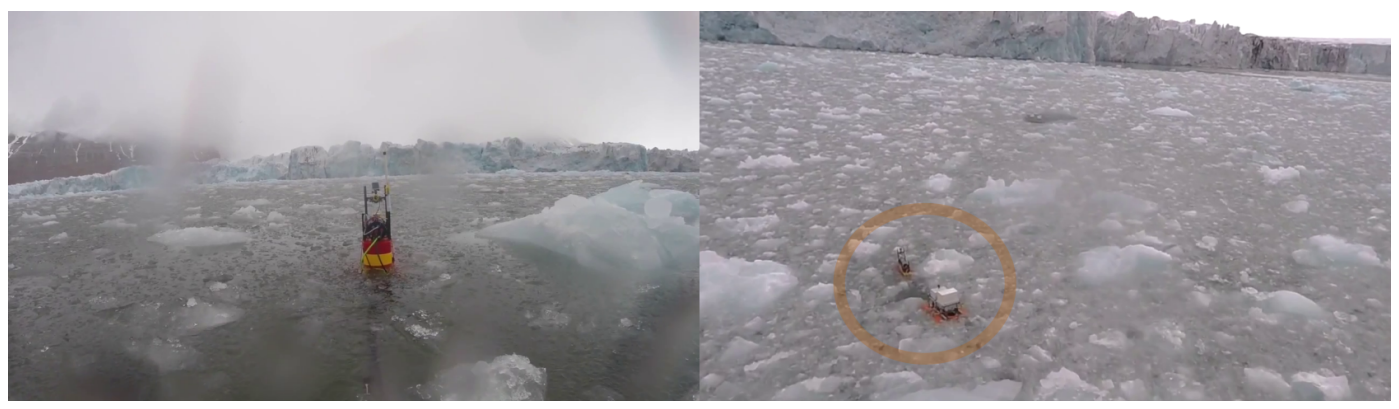

Figure 21. UVASS project: PROTEUS moving in the middle of bergy bits and growlers toward the Kronebreen and PROTEUS trapped in the ice (2017).

\subsection{EXCELLABUST Project}

From the end of May and the beginning of June 2018, a third robotic-scientific campaign was carried out in the framework of the H2020 project EXCELLABUST-Excelling LABUST in marine robotics. The campaign hosted a field training to show to a group of 12 researchers in marine robotics from universities of Zagreb, Limerick, and Girona, to show the peculiarities of operations in a polar environment, demonstrating the feasibility of the USSV-based characterisation of the water and air column in the proximity of the fronts of tidewater glaciers.

The simultaneous operations of USSV and UAVs, demonstrated in the UVASS campaign in 2017, allowed the collection of water and air parameters at the price of a rather heavy logistics on board the support vessel. Working with multiple water and air drones from MS Teisten was difficult for their remote control teams, who were forced to operate in an extremely small space. This experience, together with the availability of low-size commercial components, pushed research towards the design and development of new miniaturised data acquisition and sampling tools to be integrated aboard a single portable vehicle. The aim of the mission was to accomplish the scientific goal of studying sea-ice-atmosphere interface, profiling the parameters along the water and air column. The operational solution was developing an USSV equipped with a miniaturised water multi-sampler and two winches for the deployment and recovery of underwater and atmosphere multi-parametric gauges (see Figure 22). 


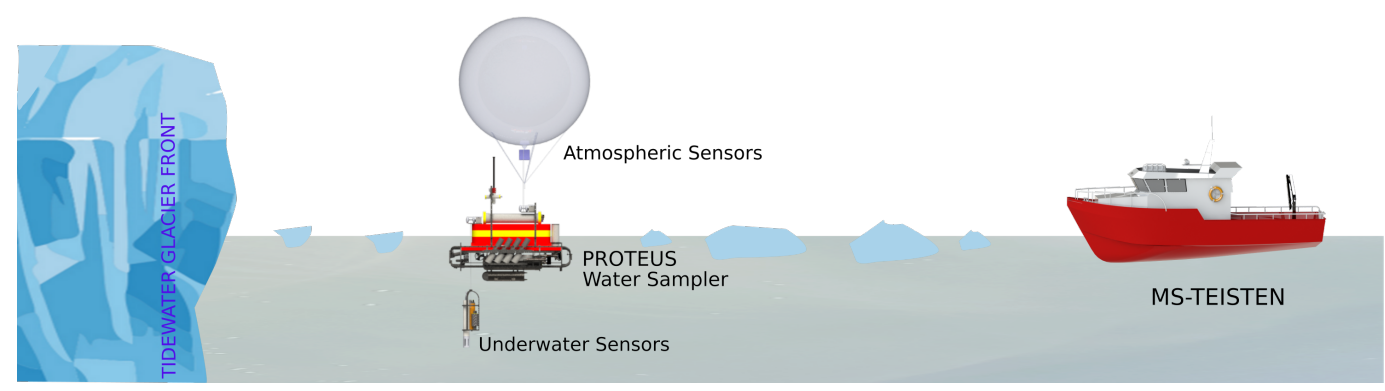

Figure 22. EXCELLABUST project: PROTEUS USSV (2018).

The installation on-board PROTEUS USSV of a new and innovative Mini Automatic Water Sampler (MAWS) for the collection of multiple water samples [50] eliminated the unwieldy trimaran and the previous multisampler. The MAWS was built with standard chemical laboratory bottles $(500 \mathrm{~mL})$ on which an automated cap based on magnetic forces generated by permanent magnets and solenoids was applied. The use of eight bottles allowed sampling at different distances from the glacier. These can be replaced by another eight after each sampling. In addition, the MAWS could be controlled remotely by means of a RS-232 serial link.

Moreover, for carrying out data acquisition in the water and air columns, two release systems based on automatic winches were installed on PROTEUS (see Figure 23). Each winch was made up of a customised fishing reel with a thread guide that was adapted so that a brushless electric motor, placed in a watertight container, could move the winch by means of a reduction box with a worm screw that allows the intrinsic brake of the winch and prevents it from being freely unrolled. This solution reduced the power consumption of the motor. The winches could be remotely controlled by PROTEUS via an Ethernet connection.

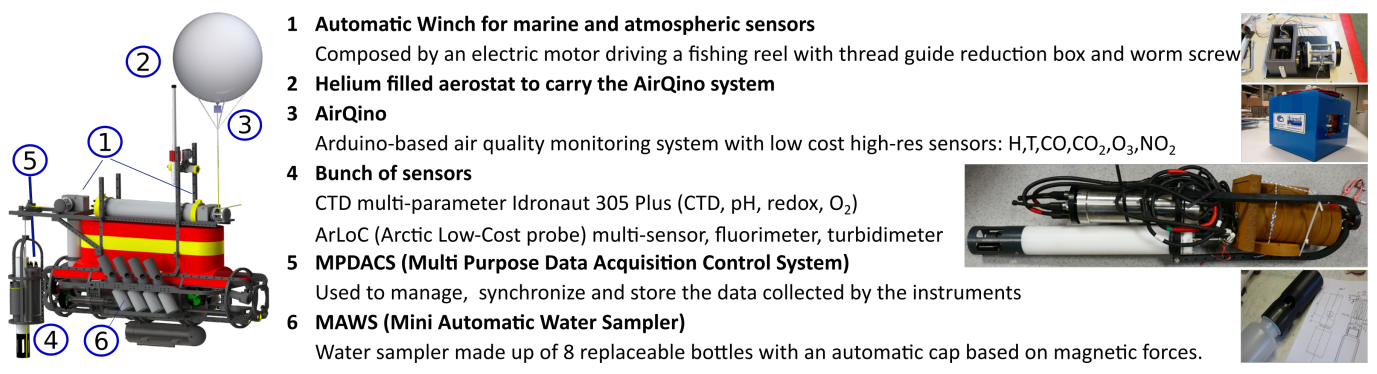

Figure 23. PROTEUS-USSV configuration in the Svalbard 2018 campaign.

The fore winch was devoted to deploy and recovery a helium-filled aerostat, carrying Dronino (a Drone version of the AirQino), a multiparametric gauge for air quality monitoring (humidity, temperature, $\mathrm{CO}, \mathrm{CO}_{2}, \mathrm{O}_{3}$, and $\mathrm{NO}_{2}$ ). The use of the aerostat in place of an UAV not only simplified operations, but also increased the duration of data acquisition in the air column. The astern winch released and recovered a set of instruments for the chemical-physical characterisation of the water column. To characterise the water as a function of depth, the following set of sensors was used: A multi-parametric Idronaut 305 Plus CTD type probe (conductivity, temperature, depth, $\mathrm{pH}$, redox, and oxygen), the ArLoC multi-sensor, a fluorimeter, and a turbidimeter. ArLoC (Arctic Low-Cost probe) is the tool for the acquisition of parameters relating to sea water designed by the University of Tuscia to be flexible, adaptable, low cost, and equipped with sensors for depth, temperature, and chlorophyll-a fluorescence. It was also used in the 2017 campaign where its reliability was evaluated by a comparison with "state-of-the-art" CTDs and by means of remote sensing data from Sentinel-2 [42]. The management of the underwater winch was performed by using an altimeter to prevent the possibility of the grounding and deadlock of the sensors.

All data collected by the cluster of instruments released underwater were synchronised and saved by an ad-hoc developed system named MPDACS (Multi Purpose Data Acquisition Control System). 
The vehicle and tools are shown in Figure 24. Even if it resulted in becoming an impediment to the navigation in the 2017 campaign, PROTEUS was again linked to the boat by means of the Dyneema rope. This was done to also prevent the vehicle from remaining stuck to the bottom due to a grounding of the underwater sensors without the possibility of detecting the position and recovering the vehicle due to the impossibility of navigating in the forbidden area. In order to increase the safety of PROTEUS an Automatic Identification System (AIS Matsutec HP-33a) was installed on-board. The AIS gives the pilot the possibility to localise and rescue the vehicle in case of faults caused by external factors (e.g., in the case PROTEUS remained stuck between the blocks of ice and it was necessary to cut the Dyneema rope).

As far as the navigation strategy and communication security is concerned, a watchdog tool was used which intervened in the event of a loss of communication for a predefined period of time (usually $30 \mathrm{~s}$ ), interrupting the generation of thrust by the motors until the communication link was restored. This was done because a loss of communication could cause the robot to apply indefinitely the last received command and this can be a very dangerous behaviour in the proximity of a glacier.

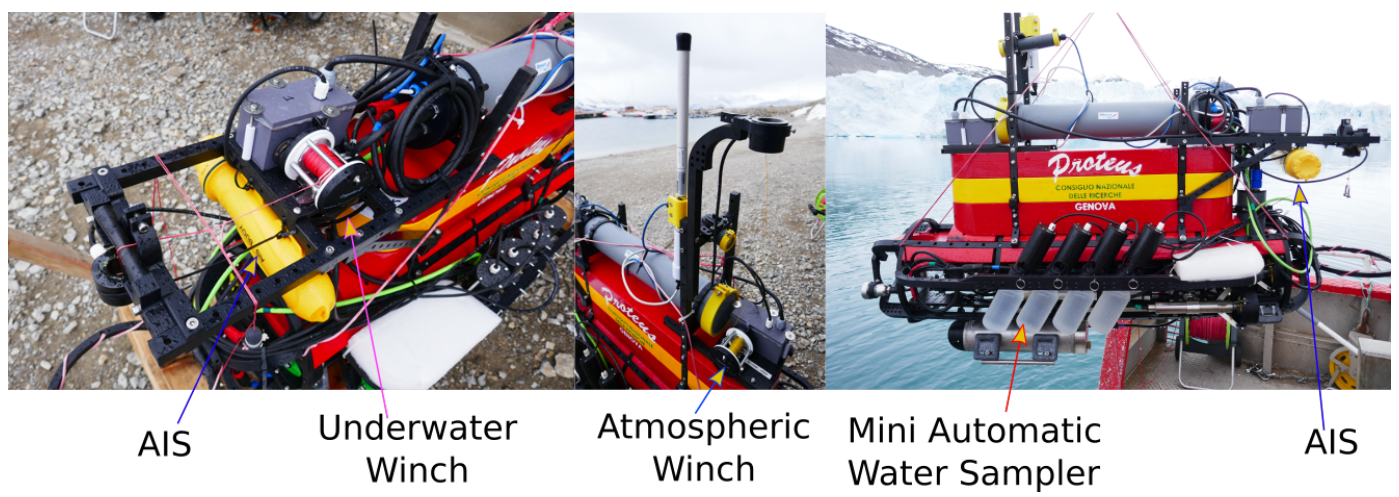

Figure 24. The integration winches and Mini Automatic Water Sampler (MAWS) on-board PROTEUS.

\subsubsection{Missions}

As reported in Table 3, during the period 25 May to 1 June, 2018, PROTEUS USSV executed various missions in the proximity of the fronts of the Blomstrandbreen, Kongsbreen, Kronebreen, and Conwaybreen glacier (see Figure 25).

Table 3. EXCELLABUST project: Missions performed in Kongsfjorden by PROTEUS enhanced USSV May-June 2018.

\begin{tabular}{|c|c|c|c|c|c|c|c|c|c|}
\hline \multirow[t]{2}{*}{ Date } & \multirow[t]{2}{*}{ Time } & \multirow[t]{2}{*}{ Where } & \multicolumn{4}{|c|}{ Water Column Sensors } & \multicolumn{2}{|c|}{ Water Sensor/Sampler (Surface) } & \multirow{2}{*}{$\begin{array}{r}\text { Air Sensor } \\
\text { Airqino }\end{array}$} \\
\hline & & & $\begin{array}{l}\text { Idronaut } \\
\text { CTD (105) }\end{array}$ & ArLoC & Fluorimeter & $\begin{array}{c}\text { Turner } \\
\text { Turbidimeter }\end{array}$ & $\begin{array}{l}\text { Idronaut } \\
\text { CTD (104) }\end{array}$ & MAWS & \\
\hline 25 May 2018 & $10: 47$ & $\begin{array}{c}\text { Bloomstrandbreen } \\
\text { (Area 1-79.02196,12.15215) }\end{array}$ & & & & & & $\mathrm{V}$ & \\
\hline 26 May 2018 & $13: 30$ & Bloomstrandbreen (Area 1) & $\mathrm{V}$ & & $\mathrm{V}$ & $\mathrm{V}$ & $\mathrm{V}$ & $\mathrm{V}$ & \\
\hline 28 May 2018 & $10: 31$ & $\begin{array}{c}\text { Bloomstrandbreen } \\
\text { (Area 2-79.00915,12.21286) }\end{array}$ & V & & V & V & V & $\mathrm{V}$ & V \\
\hline 28 May 2018 & $13: 17$ & Bloomstrandbreen (Area 2) & V & $\mathrm{V}$ & $\mathrm{V}$ & $\mathrm{V}$ & $\mathrm{V}$ & $\mathrm{V}$ & V \\
\hline 29 May 2018 & $14: 55$ & Bloomstrandbreen (Area 2) & & & & & & $\mathrm{V}$ & \\
\hline 30 May 2018 & $18: 12$ & Bloomstrandbreen (Area 2) & & & & & V & V & \\
\hline 30 May 2018 & $14: 32$ & $\begin{array}{c}\text { Kongsbreen } \\
(78.96574,12.61896)\end{array}$ & & & & & V & V & \\
\hline 01 June 2018 & 11:05 & Kongsbreen & $\mathrm{V}$ & $\mathrm{V}$ & $\mathrm{V}$ & $\mathrm{V}$ & $\mathrm{V}$ & $\mathrm{V}$ & $\mathrm{V}$ \\
\hline 30 May 2018 & 09:58 & $\begin{array}{c}\text { Kronebreen } \\
(78.88061,12.59886)\end{array}$ & & & & & V & V & \\
\hline 01 June 2018 & 14:01 & $\begin{array}{c}\text { Conwaybreen } \\
(78.99109,12.53055)\end{array}$ & V & V & V & V & V & & V \\
\hline
\end{tabular}




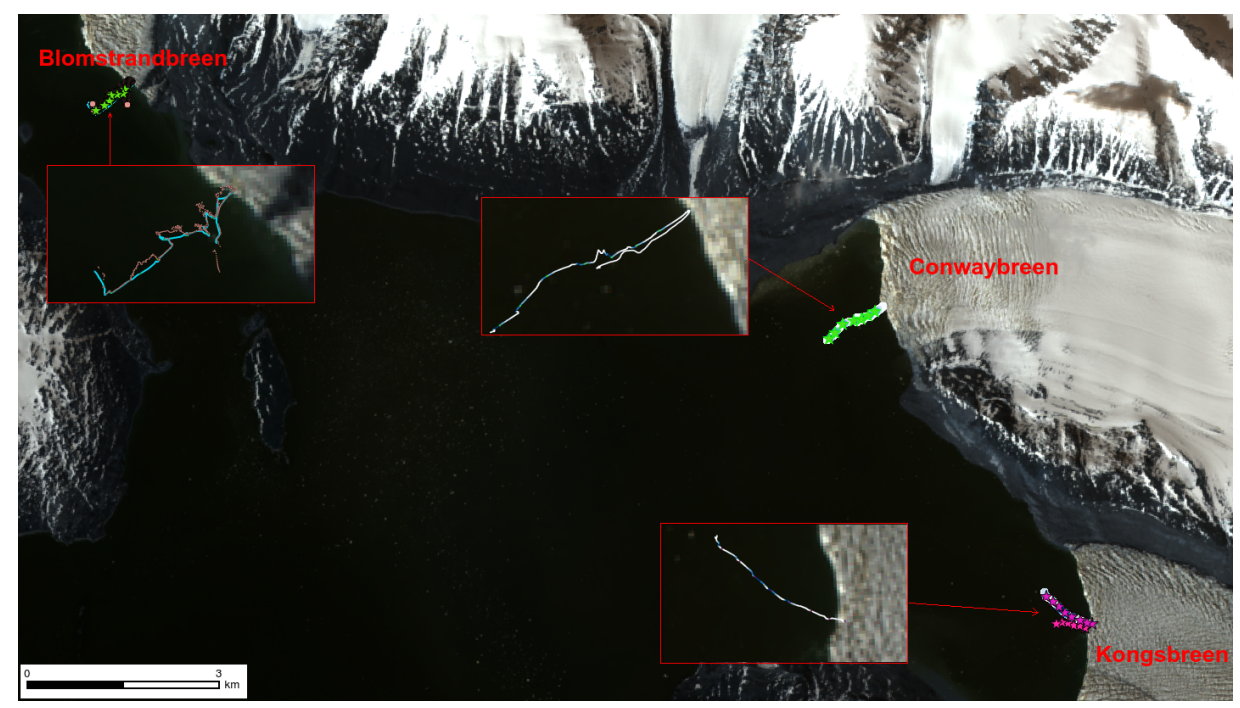

Figure 25. EXCELLABUST project: Map of the testing sites in Kongsfjorden obtained from the processing of Landsat8 data acquired on the same days in which the tests took place. The boxes show examples of GPS trajectories followed by PROTEUS USSV during data acquisition.

Complete water and air column profiles, as well as surface water sampling, were performed nearby the Blomstrandbreen and Kongsbreen glaciers. An example of the vehicle and aerostat path, as well as water sampling points, while approaching Blomstrandbreen glacier is shown in Figure 26.

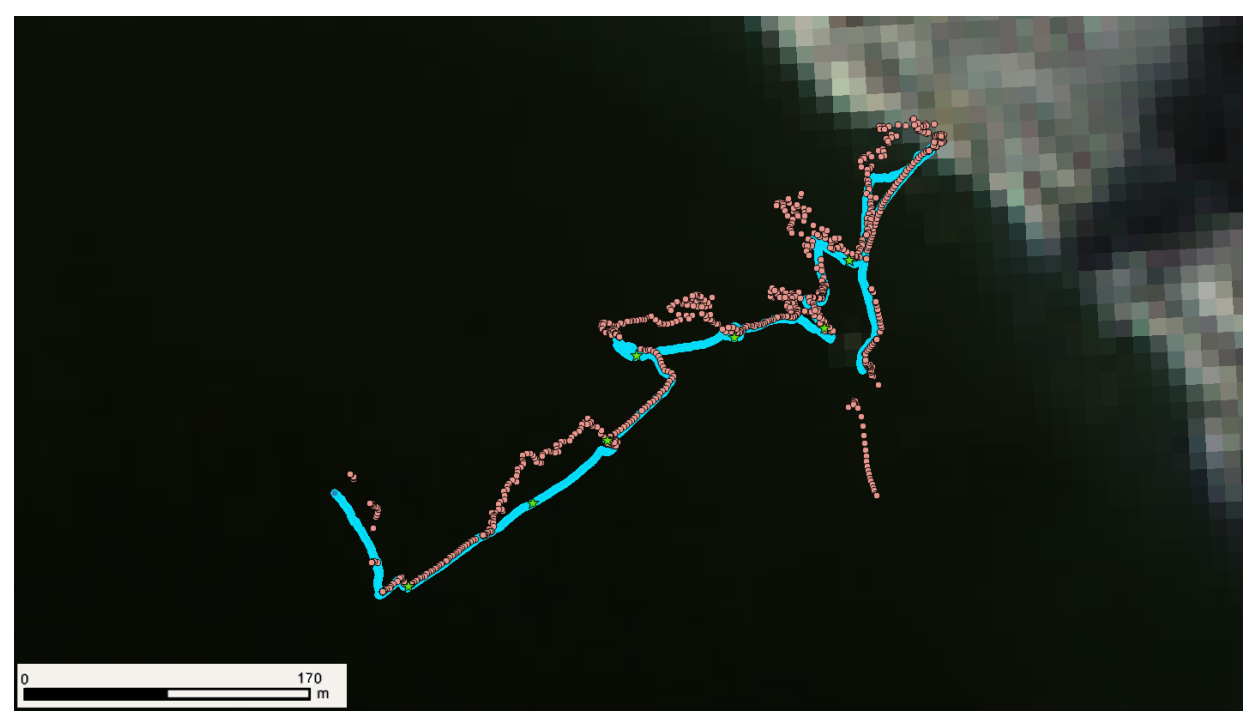

Figure 26. EXCELLABUST project: Path of PROTEUS USSV (cyan), aerostat multi-parametric gauge (pink), and water sampling points (green stars), while approaching the front of Blomstrandbreen glacier.

Figures 27 and 28 report, as an example, the profile of depth and height recorded by the CTD and by the Dronino respectively in one of the campaigns made in front of the Conwaybreen glacier with the two winches working. 

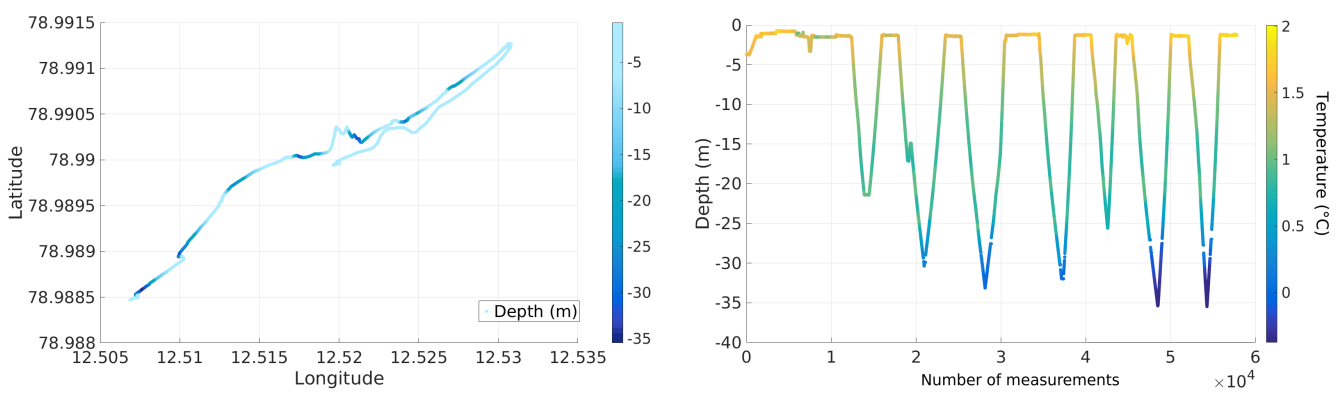

Figure 27. Conwaybreen data from the CTD moved by the winch.

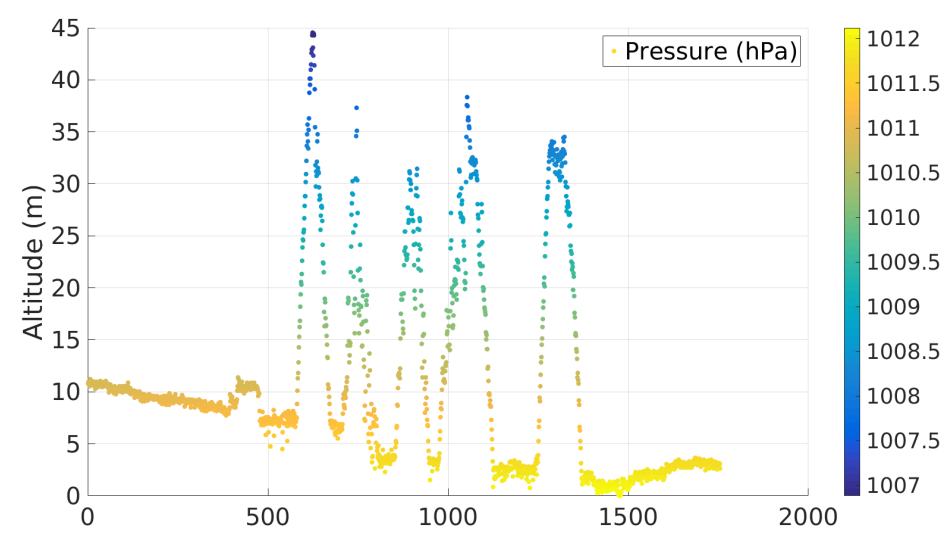

Figure 28. Conwaybreen data from the Dronino moved by the fore winch.

In Figure 27, an example of measuring campaign with automatic CTD descent is shown. On the left the path with the water depth and on the right, the profile of depth with the temperature scale showing a lower temperature on the bottom and higher just below the surface due to the fact that seawater had a peak of density at, almost, $-2^{\circ} \mathrm{C}$.

In Figure 28, the altitude of the Dronino onboard the aerostat is shown together with the pressure scale.

In Figure 29, the pictures of the mission vehicle with the aerostat are reported.

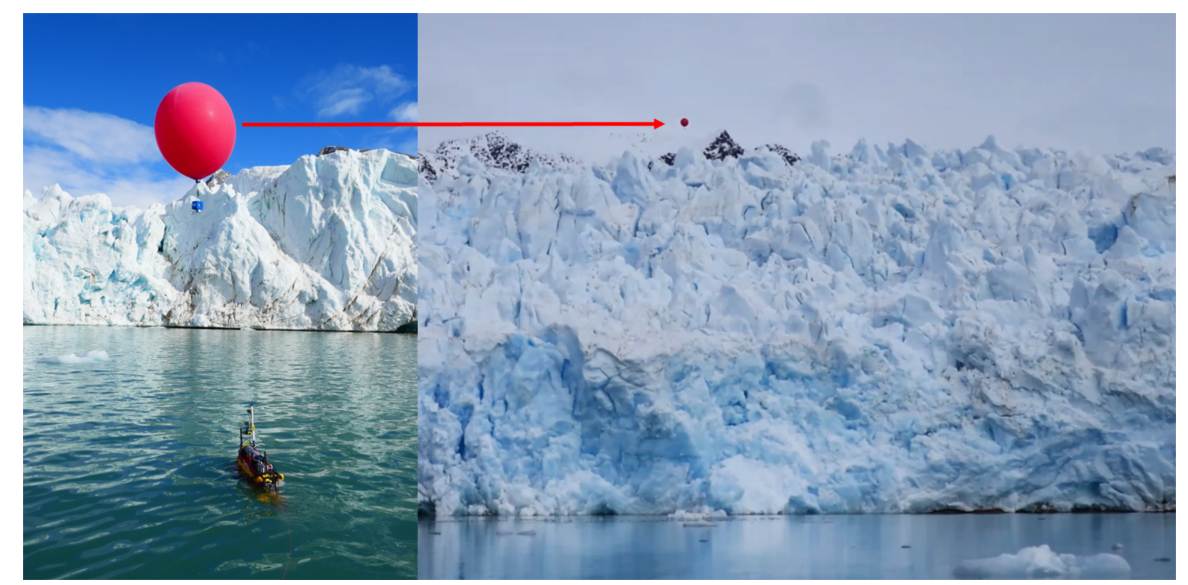

Figure 29. On the left, PROTEUS with the aerostat starting a mission. One the right, PROTEUS measuring in the direct front of the glacier.

\subsubsection{Achievements and Problems}

As far as the robotics achievements are concerned, the PROTEUS vehicle was able to reach the front of the glacier releasing Dronino and the cluster of sensors together with the MPDACS. This was 
done by sampling and sensing up to the surface of the glacier with both the aerostat released in air and the water sensors lowered with the winch. Thanks to the smaller logistics it was possible to obtain a high repeatability of the sampling and of the sensing and this was indeed the main robotic result expected from the 2018 campaign whose development and design came from the experience achieved during the 2015 and 2017 campaigns.

Moreover, operative and logistics aspects were much easier to face by using only robotics and an aerostat instead of two robots (USSV and UAV) at the same time. Furthermore, transporting of the aerostat, which initially seemed problematic, proved to be quite safe using a hot-air balloon-like lashing.

As already happened in previous campaigns, many samples were collected for microbiological purposes. In the latter campaign, moreover, samples for the study of the portion of heavy metals, which needed to be subsequently frozen, and other samples for the analysis of Persistent Organic Pollutants (POPs) were also collected.

The practical indications obtained during the campaign are the following:

- The enhancement of the vehicle by means of winches and the integrated water sampler proved to be reliable during operations at sea;

- $\quad$ The team needed one person for managing the scientific part (choice of the sampling positions) and one for managing the vehicle. This was also because, in this area, the compass does not work well;

- It was necessary to carefully take care of samplings when sampling water. Above all it is important that the samples are collected with sterile gloves and tightly closed, sealed, and frozen.

Careful attention should be paid to the preparation of the bottles and of the sampler.

As far as the technical problems encountered are concerned, some issues arose with heading management and calibration of the compass due to the proximity to the North Pole. For this reason the heading of the vehicle had to be manually managed by an operator on-board the support vessel by means of visual corrections by using the video streaming coming from a video camera located on board the vehicle. Even if the vehicle was provided with a double GPS system and compass, one placed on the vehicle and one on the USSV electronics respectively, the calibration of the compass and the dual GPS heading tests did not give good results. Actually, the low coverage of GPS signal and the disturbances in the magnetometer compass signal due to the vicinity to the magnetic North Pole affected the capability of the two systems. This is an aspect that will be used as future indication for the use of Fibre Optic Gyro that may be useful for the good management of heading.

Results originating from the data collected during the campaign have been published, among others, in [51,52]. Further scientific articles related to the above mentioned data are in preparation during the writing of this work.

\section{Lessons Learnt and Hints for Future Missions}

The three campaigns reported in this paper successfully accomplished the robotic target of increasingly improving the capacity of a robotic tool to sample and sense in a harsh environment represented by the stretch of sea in front of the tidewater glaciers.

The general success of missions was more than $90 \%$. In just a small number of cases the missions were aborted for external reasons. The failures were mostly caused by the drifting of bergy bits and growlers caused by current and wind.

The main issue related to this drifting was the presence of the safety Dyneema rope that, whenever useful in case of calm waters, became a problem if ice drifting was present and the rope remains caught in the ice preventing the robot to move freely in water.

In future missions, thanks to the reliability demonstrated by the system and the use of the AIS, the idea is not to use the safety rope anymore. This should allow the missions to be accomplished with an even higher degree of success due to the fact that there will not be anymore impediments to the navigation caused by the presence of the rope. 
The USSV configuration of the robots was chosen because in this case the hull was completely immersed and for this reason the vehicles could easily push away the bergy bits and growlers from below the sea surface. This solution allowed one to obtain a good navigation in these polar waters. The idea of using low draft high speed vehicles may become a problem in case the vessel overlaps the ice-sheets because this can prevent from a good navigation. The use of a monohull vehicle is also a good choice since the use of multiple hulls, like for example a catamaran, may also be a problem in case of growlers with the same breadth of the vessel as the vehicle can remain trapped during its path. In the case of catamarans, an additional rostrum at bow and stern could be useful to avoid the presence of floating ice.

A good solution, as far as the vehicle safety is concerned, is the use of a redundant propulsion system characterised by a number of propulsion unit. This expedient is useful to increase the probability to return home in case of problems caused by the bump with a piece of ice or by an electrical fault.

Another aspect was the important result in the accomplishment of repetitive sampling. First of all the use of a single vehicle that carries all sensors and samplers resulted to be a reliable solution. Moreover the vehicle battery sizing was chosen by considering a mission with a maximum continuous powering for $2 \mathrm{~h}$. This allowed the possibility of having adequate endurance and therefore a vehicle equipped with manifold sensors.

As far as the sampling strategy was concerned, in the first missions the vehicle sampled in the desired places on its going route. On the contrary, during the last missions the vehicle was sent at high speed near the front of the glacier to sample there its first bottle. This solution was chosen with the aim of being able to make the most interesting samples, those closest to the glacier, in the first phase of the mission. In case of problems the vehicle would have been later recovered but having been already sampled.

Regarding the sampling strategy another interesting aspect was related to the choice of the sampler. The use of the pump-based sampler used in the first campaigns required more time than the cap-based (MAWS) water sampler. The sampling time implied that, if drifting ice begins, it is difficult to sample on the desired straight path. It must be noticed that as the ice begins to drift the whole mass of water moves as a pseudo-rigid body that drags the vehicle.

In the first missions, using the principle of caution, the vehicle was used at low thrust values but the missions resulted in being long and were affected by the above mentioned ice drifting. Thus it was stated that the vehicle must be able to move faster and go to sample quickly and quickly return.

Another improvement could be to endow the vehicle with an adequately pan and tilt camera or with multiple video cameras, for example four, each one looking on each side.

Increasing the degree of autonomy of the vehicle is certainly useful. The self/safe-return to home is something that will be implemented in future missions but for this purpose a good navigation package is required. The use of a Fibre Optic Gyro could be the solution to cope with the problems encountered in the use of dual GPS and compass for measuring heading in an area close to the magnetic North Pole.

The Wi-Fi radio connection with the remote station aboard MS Teisten allowed the scientific end-user to access data in real-time and to modify the sampling area according to sampling requirements and performance. In future automatic adaptive sampling methods could also be used to perform analysis and collect data in the most interesting locations. To this end, a vehicle allowing automatic station keeping could be very useful.

\section{Conclusions}

With the field experience gained in the campaigns carried out in 2015, 2017, and 2018, the CNR marine robotics group validated the capabilities of UMVs in monitoring and sampling the sea-ice-atmosphere interface in the very proximity of glacier fronts. In particular, field experience pointed out, as previously in other Antarctic operations, the need of adapting the available technology to operational and logistic constraints. According to these practical guidelines, the design and 
development of a modular reconfigurable portable compact vehicle able to carry on surface water samplers and tools for deploying and recovery multi-parametric gauges for monitoring water and air columns was preferred to the use of a fleet of cooperative surface and air unmanned vehicles. In fact, the single vehicle solution required a lighter logistics, including a reduced number of people for robot control and operations, that could be easily hosted on-board the available support vessel.

The use of Unmanned Semi-Submersible Vehicle was advantageous since it could move well between the icebergs, growlers, and bergy bits by pushing them from the submerged part without the risk of remaining stuck or trapped as it can happen to other kind of surface vehicles.

The final evolution of the PROTEUS USSV used by adopting the on board Mini Automatic Water Sampler and the two winches was the base for a repeatable series of sampling campaigns that could be performed in only two weeks in the stretch of water in front of any tidewater glacier of Arctic or Antarctica.

In any case, marine robotics demonstrated to be an effective and efficient solution to the problem of monitoring and sampling the sea-ice-atmosphere interface in the very proximity of glacier fronts. The next technological step will consist of using the adaptation of POP-ART PROTEUS reconfigurable vehicle to work as an AUV below the floating ice tongue in order to catch the fresh water flows coming from the inner glacier.

As far as the collected data is concerned, these constitute an inestimable source of information from a physical, chemical, and biological point of view. In order to make the best use of this source of information, the data will be managed according to the FAIR principles (Findable, Accessible, Interoperable and Reusable). This implies the standardisation of the information, which must be formatted according to the typically used standards (NetCDF/CF, GeoJSON, etc.), correlated by metadata, which allow the content to be interpreted and made available for inclusion in databases such as the Italian Arctic Data Centre (IADC) and SIOS Data Management System (SDMS).

\section{Video Material}

Relevant videos showing the activities described in this paper are available at:

- 2015 campaign: https://www.youtube.com/watch?v=BMerNZhTABo

Video showing 2015 campaign as preliminary part of the UVASS project;

- 2017 campaign: https://www.youtube.com/watch?v=-hvq4dYKlhk

Video showing PROTEUS USSV trapped in the floating ice;

- 2017 campaign: https://www.youtube.com/watch?v=R-ypCpjtd3M

Video showing mission success;

- 2018 campaign: https://www.youtube.com/watch?v=JqPBKOHtFA0

Video showing EXCELLABUST activities;

- $\quad$ POP-ART concept: https://www.youtube.com/watch?v=ULFdwmwpx_s

Video showing how Proteus can transform from ROV to AUV, ASSV and ASV.

Author Contributions: Conceptualization: G.B., A.O. and M.C.; Data curation: G.B., A.O. and R.F.; Formal analysis: A.O. and R.F.; Funding acquisition: G.B., M.C.; Investigation: G.B., A.O., M.C. and R.F.; Methodology: G.B. and A.O.; Project administration: G.B. and M.C.; Resources: G.B. and M.C.; Software: G.B., R.F. and M.C.; Supervision: G.B.; Validation: G.B., A.O. and R.F.; Visualization: G.B., A.O., M.C. and R.F.; Writing-original draft: G.B., A.O., M.C. and R.F.; Writing-review \& editing: G.B., A.O., M.C. and R.F. All authors have read and agreed to the published version of the manuscript.

Funding: This work was partially funded by the projects Arctic: Present Climatic change and pAst extreme events (ARCA) and EC Horizon 2020 Twinning EXCELLABUST-Excelling LABUST in marine robotics G.A. 691980.

Acknowledgments: The authors wish to thank Arturo Argentieri, Giorgio Bruzzone, Pierpaolo Soria, and Edoardo Spirandelli, for their fundamental fieldwork, design, and development contribution during the scientific campaign. System design and development, as well as logistic organisation of the campaign, were possible thanks to the precious work of Giuseppe Camporeale, Mauro Giacopelli, and Raffaella Beroldo. The authors also wish to thank the colleagues of CNR-IAMC, CNR-ISMAR, CNR-IBIMET, and Tuscia University, for their essential collaboration and all the staff of the Base Artica Dirigibile Italia for their kind and professional support. 
Conflicts of Interest: The authors declare no conflict of interest.

\section{References}

1. Overland, J.; Dunlea, E.; Box, J.E.; Corell, R.; Forsius, M.; Kattsov, V.; Olsen, M.S.; Pawlak, J.; Reiersen, L.O.; Wang, M. The urgency of arctic change. Polar Sci. 2018, 21, 6-13. [CrossRef]

2. Wadhams, P. A Farewell to Ice: A Report from the Arctic; Oxford University Press; Oxford, UK: 2017.

3. Solomon, S. IPCC (2007): Climate change the physical science basis. In AGU Fall Meeting Abstracts; Advancing Earth and Space Science: Washington, DC, USA, 2007.

4. Stocker, T.F.; Qin, D.; Plattner, G.K.; Tignor, M.; Allen, S.K.; Boschung, J.; Nauels, A.; Xia, Y.; Bex, V.; Midgley, P.M.; et al. Climate Change 2013: The Physical Science Basis; Cambridge University Press: New York, NY, USA, 2013.

5. Svendsen, H.; Beszczynska-Møller, A.; Hagen, J.O.; Lefauconnier, B.; Tverberg, V.; Gerland, S.; Børre Ørbæk, J.; Bischof, K.; Papucci, C.; Zajaczkowski, M.; et al. The physical environment of Kongsfjorden-Krossfjorden, an Arctic fjord system in Svalbard. Polar Res. 2002, 21, 133-166, doi:10.3402/polar.v21i1.6479. [CrossRef]

6. Katrin, L.; Kohler, J.; Pettersson, R.; Nuth, C.; Langley, K.; Messerli, A.; Vallot, D.; Keniche, M.; Brandt, O. Subglacial topography, ice thickness, and bathymetry of Kongsfjorden, northwestern Svalbard. Earth Syst. Sci. Data 2018, 10, 1769-1781.

7. Torsvik, T.; Albretsen, J.; Sundfjord, A.; Kohler, J.; Sandvik, A.D.; Skarðhamar, J.; Lindbäck, K.; Everett, A. Impact of tidewater glacier retreat on the fjord system: Modeling present and future circulation in Kongsfjorden, Svalbard. Estuar. Coast. Shelf Sci. 2019, 220, 152-165.

8. Hübner, C.; Lihavainen, H.; Jennings, I.; Jawak, S.; Godøy, Ø.; Andersen, B.; Kuckero, L.; Orr, E.; Hansen, G.; Lappalainen, H. Improving Arctic Observation Systems through coordination-examples from the first State of Environmental Science in Svalbard (SESS) report. In Geophysical Research Abstracts; European Geosciences Union: Munich, Germany, 2019; Volume 21.

9. Schellenberger, T.; Dunse, T.; Kääb, A.; Kohler, J.; Reijmer, C. Surface speed and frontal ablation of Kronebreen and Kongsbreen, NW-Svalbard, from SAR offset tracking. Cryosphere Discuss. 2014, 8, 6193-6233. [CrossRef]

10. Kohler, J.; James, T.; Murray, T.; Nuth, C.; Brandt, O.; Barrand, N.E.; Aas, H.; Luckman, A. Acceleration in thinning rate on western Svalbard glaciers. Geophys. Res. Lett. 2007, 34. [CrossRef]

11. Neal, M.; Blanchard, T.; Hubbard, A.; Chauché, N.; Bates, R.; Woodward, J. A hardware proof of concept for a remote-controlled glacier-surveying boat. J. Field Robot. 2012, 29, 880-890.

12. Sauze, C.; Neal, M.; Blanchard, T.; Miller, P. An Ice Strengthened Autonomous Surface Vessel for Surveying Marine-Terminating Calving Glaciers. J. Ocean Technol. 2015, 10, 86-111.

13. Kimball, P.; Bailey, J.; Das, S.; Geyer, R.; Harrison, T.; Kunz, C.; Manganini, K.; Mankoff, K.; Samuelson, K.; Sayre-McCord, T.; et al. The whoi jetyak: An autonomous surface vehicle for oceanographic research in shallow or dangerous waters. In Proceedings of the 2014 IEEE/OES Autonomous Underwater Vehicles (AUV), Oxford, MS, USA, 6-9 October 2014; pp. 1-7.

14. Stevens, L.A.; Straneo, F.; Das, S.B.; Plueddemann, A.J.; Kukulya, A.L.; Morlighem, M. Linking glacially modified waters to catchment-scale subglacial discharge using autonomous underwater vehicle observations. Cryosphere 2016, 10, 417-432.

15. Carlson, D.F.; Pasma, J.; Jacobsen, M.E.; Hansen, M.H.; Thomsen, S.; Lillethorup, J.P.; Tirsgaard, F.S.; Flytkjær, A.; Melvad, C.; Laufer, K.; et al. Retrieval of ice samples using the Ice Drone. Front. Earth Sci. 2019, 7, 287. [CrossRef]

16. Carlson, D.F.; Fürsterling, A.; Vesterled, L.; Skovby, M.; Pedersen, S.S.; Melvad, C.; Rysgaard, S. An affordable and portable autonomous surface vehicle with obstacle avoidance for coastal ocean monitoring. Hardwarex 2019, 5, e00059. [CrossRef]

17. Howe, J.A.; Husum, K.; Inall, M.E.; Coogan, J.; Luckman, A.; Arosio, R.; Abernethy, C.; Verchili, D. Autonomous underwater vehicle (AUV) observations of recent tidewater glacier retreat, western Svalbard. Mar. Geol. 2019, 417, 106009, doi:10.1016/j.margeo.2019.106009. [CrossRef]

18. Overpeck, J.; Hughen, K.; Hardy, D.; Bradley, R.; Case, R.; Douglas, M.; Finney, B.; Gajewski, K.; Jacoby, G.; Jennings, A.; et al. Arctic environmental change of the last four centuries. Science 1997, 278, 1251-1256. [CrossRef] 
19. Hop, H.; Wiencke, C. The Ecosystem of Kongsfjorden, Svalbard. In The Ecosystem of Kongsfjorden, Svalbard; Springer: Cham, Switzerland, 2019; pp. 1-20.

20. D'Angelo, A.; Giglio, F.; Miserocchi, S.; Sanchez-Vidal, A.; Aliani, S.; Tesi, T.; Viola, A.; Mazzola, M.; Langone, L. Multi-year particle fluxes in Kongsfjorden, Svalbard. Biogeosciences 2018, 15, 5343-5363.

21. Halbach, L.; Vihtakari, M.; Duarte, P.; Everett, A.; Granskog, M.A.; Hop, H.; Kauko, H.M.; Kristiansen, S.I.; Myhre, P.I.; Pavlov, A.K.; et al. Tidewater Glaciers and Bedrock Characteristics Control the Phytoplankton Growth Environment in a Fjord in the Arctic. Front. Mar. Sci. 2019, 6, 254. [CrossRef]

22. Calleja, M.L.; Kerhervé, P.; Bourgeois, S.; Kędra, M.; Leynaert, A.; Devred, E.; Babin, M.; Morata, N. Effects of increase glacier discharge on phytoplankton bloom dynamics and pelagic geochemistry in a high Arctic fjord. Prog. Oceanogr. 2017, 159, 195-210, doi:10.1016/j.pocean.2017.07.005. [CrossRef]

23. Maturilli, M.; Dahlke, S.; Kayser, M.; Boike, J.; Fischer, P. Symptoms of Arctic Amplification Observed in Ny-Ålesund; Norwegian Research Council: Oslo, Norway, 2017.

24. Lilja Bye, B. Svalbard Integrated Arctic Earth Observing System-A New Coordinated Foundation for Environmental Services in and around Svalbard. In EGU General Assembly Conference Abstracts; European Geosciences Union: Munich, Germany: 2015; Volume 17.

25. Cappelletti, D.; Azzolini, R.; Langone, L.; Ventura, S.; Viola, A.; Aliani, S.; Vitale, V.; Brugnoli, E. Environmental changes in the Arctic: An Italian perspective. Rend. Lincei 2016, 27, 1-6. [CrossRef]

26. Kings Bay. Kings Bay has the Role of Facilitator in Ny Alesund Activities. Available online: https: / / kingsbay.no/ (accessed on 25 March 2020).

27. The International Air Transport Association (IATA). The Trade Association for the World's Airlines. Available online: https:/ / www.iata.org/en/programs/cargo/dgr/lithium-batteries/ (accessed on 25 March 2020).

28. Bruzzone, G.; Bibuli, M.; Zereik, E.; Ranieri, A.; Caccia, M. Cooperative adaptive guidance and control paradigm for marine robots in an emergency ship towing scenario. Int. J. Adapt. Control Signal Process. Mar. Syst. 2017, 31, 562-580, doi:10.1002/acs.2667. [CrossRef]

29. Zappalà, G.; Bruzzone, G.; Caruso, G.; Azzaro, M. Development of an automatic sampler for extreme polar environments: first in situ application in Svalbard Islands. Rend. Lincei 2016, 27, 251-259, doi:10.1007/s12210-016-0539-1. [CrossRef]

30. Guidetti, P.; Ghigliotti, L.; Vacchi, M. Insights into spatial distribution patterns of early stages of the Antarctic silverfish, Pleuragramma antarctica, in the platelet ice of Terra Nova Bay, Antarctica. Polar Biol. 2015, 38, 333-342. [CrossRef]

31. Odetti, A.; Bruzzone, G.; Caccia, M.; Spirandelli, E.; Bruzzone, G. P2-ROV a portable/polar ROV. In Proceedings of the OCEANS 2017-Aberdeen, Aberdeen, UK, 19-22 June 2017; pp. 1-6.

32. Carotenuto, F.; Brilli, L.; Gioli, B.; Gualtieri, G.; Vagnoli, C.; Mazzola, M.; Viola, A.P.; Vitale, V.; Severi, M.; Traversi, R.; et al. Long-Term Performance Assessment of Low-Cost Atmospheric Sensors in the Arctic Environment. Sensors 2020, 20, 1919. [CrossRef] [PubMed]

33. Cavaliere, A.; Carotenuto, F.; Di Gennaro, F.; Gioli, B.; Gualtieri, G.; Martelli, F.; Matese, A.; Toscano, P.; Vagnoli, C.; Zaldei, A. Development of Low-Cost Air Quality Stations for Next Generation Monitoring Networks: Calibration and Validation of PM2. 5 and PM10 Sensors. Sensors 2018, 18, 2843. [CrossRef] [PubMed]

34. Bono, R.; Bruzzone, G.; Caccia, M.; Grassia, F.; Spirandelli, E.; Veruggio, G. ROBY goes to Antarctica. In Proceedings of the OCEANS '94, Brest, France, 13-16 September 1994; Volume 3, pp. 621-625.

35. Bono, R.; Bruzzone, G.; Caccia, M.; Spirandelli, E.; Veruggio, G. Romeo goes to Antarctica [unmanned underwater vehicle]. In Proceedings of the OCEANS '98 Conference Proceedings, Nice, France, 28 September-1 October 1998; Volume 3, pp. 1568-1572, doi:10.1109/OCEANS.1998.726336. [CrossRef]

36. Bono, R.; Bruzzone, G.; Bruzzone, G.; Caccia, M.; Spirandelli, E.; Veruggio, G. Romeo ROV Antarctic exploitation for benthic research. In Proceedings of the 7th IFAC Conference on Manoeuvring and Control of Marine Craft, Lisbon, Portugal, 20-22 September 2006.

37. Caccia, M.; Bono, R.; Bruzzone, G.; Bruzzone, G.; Spirandelli, E.; Veruggio, G.; Stortini, A.; Capodaglio, G. Sampling sea surface with SESAMO. IEEE Robot. Autom. Mag. 2005, 12, 95-105. [CrossRef]

38. Bruzzone, G.; Bono, R.; Bruzzone, G.; Caccia, M.; Cini, M.; Coletta, P.; Maggiore, M.; Spirandelli, E.; Veruggio, G. Internet-based satellite teleoperation of the ROMEO ROV in Antarctica. In Proceedings of the 10th Mediterranean Conference on Control and Automation, Lisbon, Portugal, 9-12 July 2002. 
39. Bruzzone, G.; Bono, R.; Caccia, M.; Coletta, P.; Veruggio, G. Internet-based satellite tele-operation of the Romeo ROV in the Arctic region. Proc. MCMC 2003, 2003, 304-308.

40. Bruzzone, G.; Odetti, A.; Caccia, M. Remote Data Collection Near Marine Glacier Fronts - Unmanned Vehicles for Autonomous Sensing, Sampling in the North Pole. Sea Technol. 2018, 59, 22-26.

41. Piermattei, V.; Madonia, A.; Bonamano, S.; Martellucci, R.; Bruzzone, G.; Ferretti, R.; Odetti, A.; Azzaro, M.; Zappalà, G.; Marcelli, M. Application of a low cost instrumentation in Arctic extreme conditions. In Proceedings of the 4th International Electronic Conference on Sensors and Applications, Basel, Switzerland, 15-30 November 2017; Multidisciplinary Digital Publishing Institute: Basel, Switzerland, 2017.

42. Piermattei, V.; Madonia, A.; Bonamano, S.; Martellucci, R.; Bruzzone, G.; Ferretti, R.; Odetti, A.; Azzaro, M.; Zappalà, G.; Marcelli, M. Cost-effective technologies to study the arctic ocean environment. Sensors 2018, 18, 2257. [CrossRef]

43. Odetti, A.; Caccia, M.; Ferretti, R.; Ranieri, A.; Azzaro, M.; Caruso, G.; Zappalà, G.; Carotenuto, F.; Zaldei, A.; Viola, A.; et al. Unmanned Vehicles for Autonomous Sensing and Sampling 2017 Scientific Campaign. In Proceedings of the SCAR/IASC Open Science Conference POLAR 2018, Davos, Switzerland, 19-23 June 2018.

44. Azzaro, M.; La Ferla, R.; Maimone, G.; Azzaro, F.; Caruso, G.; Cabral, A.; Paranhos, R.; Crisafi, E.; Caccia, M.; Ferretti, R.; et al. Automatic sampling near an Arctic glacier: first microbial results. In Proceedings of the SCAR/IASC Open Science Conference POLAR 2018, Davos, Switzerland, 19-23 June 2018.

45. Azzaro, M.; Zappalà, G.; La Ferla, R.; Miserocchi, S.; Tesi, T.; Maimone, G.; Caruso, G.; Ferretti, R.; Odetti, A.; Azzaro, F.; et al. Microbial metabolism in front of Kongsfjorden glaciers. In Proceedings of the SCAR/IASC Open Science Conference POLAR 2018, Davos, Switzerland, 19-23 June 2018.

46. Ferretti, R. Caccia, M.; Odetti, A.; Ranieri, A. Carotenuto, F.; Zaldei, A.; Viola, A.; Bruzzone, G. Water-Air column characterisation in Arctic region using Unmanned Vehicles. In Proceedings of the SCAR/IASC Open Science Conference POLAR 2018, Davos, Switzerland, 19-23 June 2018.

47. Piermattei, V.; Madonia, A.; Bonamano, S.; Martellucci, R.; Bruzzone, G.; Caccia, C.; Ferretti, R.; Odetti, A.; Azzaro, M.; Marcelli, M. Preliminary results of an experimental survey in Kongsfjorden area. In Proceedings of the SCAR/IASC Open Science Conference POLAR 2018, Davos, Switzerland, 19-23 June 2018.

48. Ferretti, R.; Caccia, M.; Odetti, A.; Ranieri, A.; Carotenuto, F.; Zaldei, A.; Bruzzone, G. Exploitation of an Unmanned Aerial Vehicle to characterize the air-sea interface near glacier fronts in the Arctic region. In EGU General Assembly Conference Abstracts; European Geosciences Union: Munich, Germany, 2018 ; Volume 20, p. 6753.

49. Piermattei, V.; Madonia, A.; Bonamano, S.; Martellucci, R.; Bruzzone, G.; Caccia, C.; Ferretti, R.; Odetti, A.; Fiori, E.; Marcelli, M. Low-cost technological advances supporting the assessment of anthropogenic pressures on marine ecosystems. In EGU General Assembly Conference Abstracts; European Geosciences Union: Munich, Germany, 2018; Volume 20, p. 8217.

50. Odetti, A.; Bruzzone, G.; Caccia, M.; Ferretti, R.; Spirandelli, E.; Bruzzone, G. Design, development and testing at field of a modular Mini Automatic Water Sampler (MAWS) based on magnetic activation. In Proceedings of the OCEANS 2019-Marseille, Marseille, France, 17-20 June 2019; pp. 1-8.

51. Pasculli, L.; Piermattei, V.; Madonia, A.; Bruzzone, G.; Odetti, A.; Ferretti, R.; Bonamano, S. Study of glaciers melting impacts on physical and biological processes through the application of cost-effective technology in the Kongsfjorden (Svalbard). In Geophysical Research Abstracts; European Geosciences Union: Munich, Germany, 2019; Volume 21.

52. Caccia, M.; Ferretti, R.; Odetti, A.; Ranieri, A.; Bruzzone, G.; Spirandelli, E.; Bruzzone, G. Marine robotics for sampling air-sea-ice interface in the Arctic region. In Geophysical Research Abstracts, Proceedings of the EGU General Assembly 2019, Vienna, Austria, 7-12 April 2019; European Geosciences Union: Munich, Germany, 2019; Volume 21.

(C) 2020 by the authors. Licensee MDPI, Basel, Switzerland. This article is an open access article distributed under the terms and conditions of the Creative Commons Attribution (CC BY) license (http:/ / creativecommons.org/licenses/by/4.0/). 